\title{
ANTIBACTERIAL ACTIVITY AND CHEMICAL MODIFICATIONS OF PS-5 AT THE C-3 SIDE CHAIN
}

\author{
Michiko SaKamoto, Ken-ichi Yamamoto, Kunio Isshiki, Tomoyuki Ishikura, \\ YASUO FuKagawa and TaKeO YoshIOKA \\ Sanraku Inc., Central Research Laboratories, \\ 4-9-1 Johnan, Fujisawa 251, Japan \\ (Received for publication January 10, 1990)
}

\begin{abstract}
Using PS- 5 as starting material, the effects of chemical modification at the C- 3 side chain were studied on the antibacterial activity against Gram-positive and Gram-negative bacteria including $\beta$-lactamase-producers. Among 35 side chains tested, 4-pyridylthio showed the highest antibacterial activity against the Gram-positive bacteria, and D-cysteinyl against the Gram-negative microbes. In general, compared with acetamidoethylthio in PS-5, basic side chains showed improved antibacterial activity against the staphylococci and pseudomonads, whereas the antibiotic activity against the Gram-negative bacteria decreased with bulky side chains. The introduction of 6 -aminopenicillanate and 7 -aminocephalosporanate to the $\mathrm{C}-3$ side chain of carbapenem significantly reduced the antibacterial activity against the $\beta$-lactamase-producing microbes.
\end{abstract}

Naturally-occurring carbapenem compounds such as PS-5 have a marked $\beta$-lactamase-inhibitory activity ${ }^{11}$ together with a broad spectrum of potent antimicrobial activity against Gram-positive and Gram-negative bacteria. ${ }^{2)}$ However they are inferior to penicillins and cephalosporins in physico-chemical and biological stability, which hampers their clinical use.

PS-series carbapenems such as PS- $5^{2)}$, PS- $6^{3)}$, PS- $7^{3)}$ and PS- ${ }^{4)}$ are structurally characterized by their side chains at C-3 and C-6 (Fig. 1). Like other naturally-occurring carbapenem compounds, PS-5 is

Fig. 1. Strucrures of PS-series carbapenem and related compounds.

PS-series carbapenems

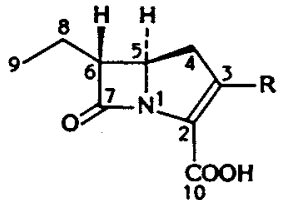

PS-5 $\quad \mathrm{R}=\mathrm{SCH}_{2} \mathrm{CH}_{2} \mathrm{NHCOCH}_{3}$ PS-7 $\mathrm{R}=\mathrm{SCH}=\mathrm{CHNHCOCH}_{3}$

Thienamycins

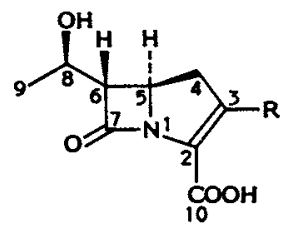

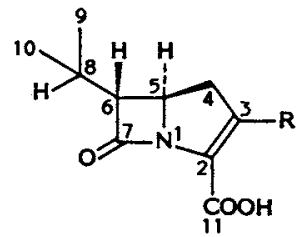

PS-6 $\mathrm{R}=\mathrm{SCH}_{2} \mathrm{CH}_{2} \mathrm{NHCOCH}_{3}$ PS-8 $\mathrm{R}=\mathrm{SCH}=\mathrm{CHNHCOCH}_{3}$

88617

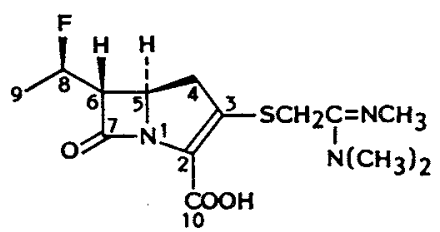

Thienamycin $\mathrm{R}=\mathrm{SCH}_{2} \mathrm{CH}_{2} \mathrm{NH}_{2}$ Imipenem $\mathrm{R}=\mathrm{SCH}_{2} \mathrm{CH}_{2} \mathrm{NH}-\mathrm{CH}=\mathrm{NH}$ 
Fig. 2. Sulfoxide method (Route A) and its modification (Route B).<smiles>CCC1C(=O)N2C(C(=O)O[Na])=C(SCCNC(C)=O)C[C@H]12</smiles><smiles>[R15]OC(=O)C1=C([S](O)CCNC(C)=O)C[C@@H]2C(CC)C(=O)N12</smiles>

Route A<smiles>[R5]OC(=O)C1=C([R]O[Sb])C[C@H]2C(CC)C(=O)N12</smiles>

Ester ( $P N B)$<smiles>[R]C1=C(C(=O)O)N2C(=O)C(CC)[C@H]2C1</smiles>

Acid

PS-5-OPNB·SO

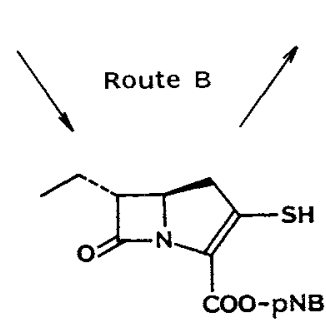

also physico-chemically unstable and susceptible to dehydropeptidase-I (DHP-I) in vitro ${ }^{5)}$ and in vivo ${ }^{6}$, resulting in poor urinary recovery after parenteral administration. PS-5 is antimicrobially inferior to thienamycin in anti-pseudomonal activity. As is the case with the penicillin and cephalosporin antibiotics, however, the above clinical disadvantages of PS-5 and related carbapenem compounds may be overcome by chemical and biological modifications. To pursue this line of approach, a practically useful synthetic process named "the sulfoxide method" has been developed. It consists of treatment of carbapenem ester sulfoxides with a variety of thiol compounds, and it offers an efficient replacement of the C-3 side chain of carbapenem compounds (Fig. 2) ${ }^{7,8}$.

This paper describes the structure-antimicrobial activity relationships of 34 PS-5 carbapenem derivatives which were prepared by the sulfoxide method and its modification, with particular reference to the antibacterial activity against Gram-positive and Gram-negative bacteria including $\beta$-lactamaseproducing strains.

\section{Results and Discussion}

\section{Structures and Derivation Yields of PS-5 Derivatives}

Table 1 shows the side chain structures and derivation yields of PS-5 derivatives modified at the C-3 side chain.

For ease of comparison, the 35 PS-5 derivatives are divided into 4 groups depending on the common structures of the C-3 side chain, and their antibacterial activities were examined against Gram-positive and Gram-negative test microorganisms including $\beta$-lactamase-producers. 
Table 1. Recovery yields of $S$-substituted carbapenem derivatives.

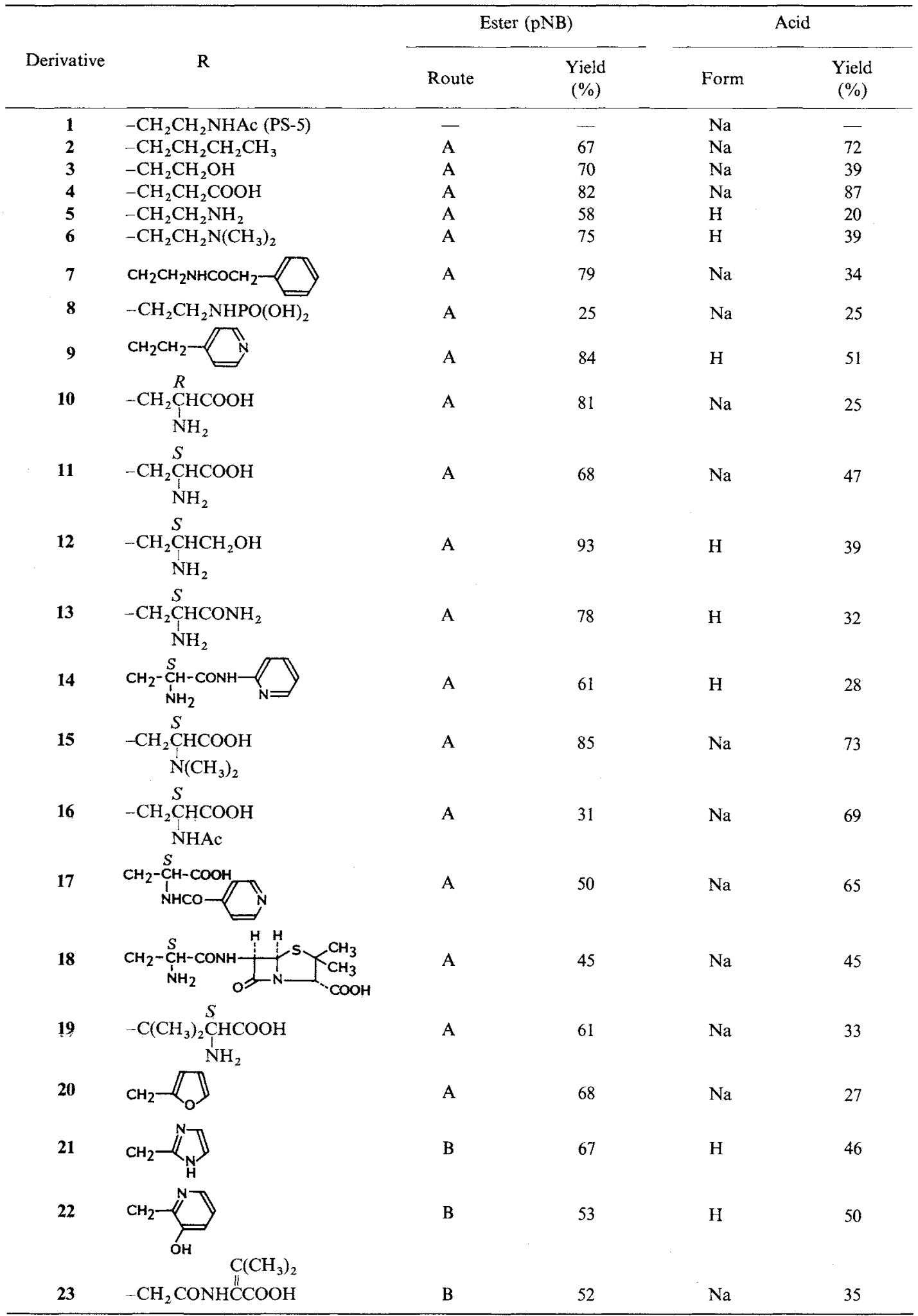


Table 1. (Continued)

Derivative

Antibacterial Activity against Standard Strains of

Gram-positive and Gram-negative Bacteria

In Table 2, a common structure of " $-\mathrm{S}-\mathrm{CH}_{2}-\mathrm{CH}_{2}$ " in the $\mathrm{C}-3$ side chain of PS-5 is modified with a variety of substituents. Compared with acetamidoethylthio in PS-5 (parent; derivative 1), the elongation of the common structure by ethyl (derivative 2) results in overall reduction of the antibiotic potency. The introduction of a hydroxyl function (derivative 3) has no influence on the antibacterial activity against the Gram-positive microbes, but slightly reduces the activity against the Gram-negative microbes. Carboxylation (derivative 4) decreases the antibacterial activity against not only the Gram-positive but also the Gram-negative microorganisms. Derivative 5 (deacetyl PS-5 or NS-5) is chemically comparable to thienamycin, as both have a free amino group at the terminus of the C-3 side chain. Like thienamycin, NS- 5 has better antibacterial activity than PS-5 against the Gram-positive bacteria, because of higher basicity. It is interesting to indicate that, as far as the Gram-negative microbes are concerned, only the anti-pseudomonal activity is improved by deacetylation of PS-5, while the other test microbes show less 
Table 2. Comparative antibacterial activities of PS-5 derivatives (1) MIC $(\mu \mathrm{g} / \mathrm{ml})$

\begin{tabular}{|c|c|c|c|c|c|c|c|c|}
\hline & \multicolumn{8}{|c|}{ Derivative } \\
\hline & 1 (PS-5) & $\mathbf{1}^{\mathbf{a}}$ & 2 & 3 & 4 & 5 & 6 & 7 \\
\hline \multicolumn{9}{|l|}{ Gram-positive bacteria: } \\
\hline Bacillus subtilis ATCC 6633 & 0.05 & 0.10 & 3.75 & 0.10 & 0.39 & 0.05 & 0.10 & 0.06 \\
\hline $\begin{array}{l}\text { Micrococcus luteus } \\
\text { ATCC } 9341\end{array}$ & 0.05 & 0.10 & 1.88 & 0.10 & 1,56 & 0.024 & 0.20 & 0.03 \\
\hline $\begin{array}{l}\text { Staphylococcus aureus } \\
\text { FDA 209P }\end{array}$ & 0.024 & 0.024 & 0.24 & 0.05 & 0.78 & 0.0001 & $<0.006$ & 0.01 \\
\hline S. aureus Smith & 0.10 & 0.10 & & 0.10 & 1.56 & 0.003 & 0.024 & 0.10 \\
\hline S. aureus Russel $^{b}$ & 0.10 & 0.10 & & 0.20 & 1.56 & 0.024 & 0.20 & 0.10 \\
\hline S. epidermidis & 0.20 & 0.20 & 0.12 & 0.20 & 1.56 & 0.05 & 0.20 & 0.20 \\
\hline \multicolumn{9}{|l|}{ Gram-negative bacteria: } \\
\hline Alcaligenes faecalis A1 & 0.39 & 0.78 & 15.0 & 1.56 & 0.78 & 1.56 & 3.13 & 0.86 \\
\hline Citrobacter freundii $\mathrm{GN} 346^{\mathrm{c}}$ & 3.13 & 3.13 & $>60$ & 3.13 & 25 & 6.25 & 12.5 & 27.5 \\
\hline Comamonas terrigena B-996 & 0.024 & 0.012 & 0.24 & 0.024 & 0.024 & 0.05 & 0.05 & $<0.007$ \\
\hline Enterobacter aerogenes $\mathrm{E} 19^{c}$ & 3.13 & 1.56 & $>60$ & 3.13 & 6.25 & 6.25 & 25 & 27.5 \\
\hline E. cloacae $45^{\mathrm{c}}$ & 3.13 & 3.13 & & 6.25 & 25 & 12.5 & 25 & 55 \\
\hline Enterobacter sp. E8 ${ }^{\mathrm{c}}$ & 3.13 & 3.13 & $>60$ & 3.13 & 3.13 & 6.25 & 12.5 & 6.88 \\
\hline Escherichia coli $\mathrm{K}-12$ & 1.56 & 1.56 & $>60$ & 3.13 & 3.13 & 6.25 & 12.5 & 3.43 \\
\hline E. coli $\mathrm{RGN} 823^{\mathrm{b}}$ & 3.13 & 1.56 & $>60$ & 12.5 & 6.25 & 3.13 & 12.5 & 13.8 \\
\hline Klebsiella pneumoniae $\mathrm{K} 13^{\mathrm{b}}$ & 3.13 & 3.13 & $>60$ & 12.5 & 6.25 & 6.25 & 25 & 27.5 \\
\hline Proteus mirabilis $\mathrm{P} 6$ & 6.25 & 6.25 & $>60$ & 12.5 & 6.25 & 12.5 & 50 & 6.88 \\
\hline$P$. rettgeri $\mathrm{P} 7^{\mathrm{c}}$ & 3.13 & 3.13 & $>60$ & 12.5 & 3.13 & 12.5 & 50 & 13.8 \\
\hline P. vulgaris $\mathrm{GN} 76^{\mathrm{c}}$ & 6.25 & 6.25 & $>60$ & 25 & 6.25 & 12.5 & 50 & 55 \\
\hline Proteus sp. $\mathrm{P} 22^{\mathfrak{c}}$ & 6.25 & 12.5 & $>60$ & 50 & 6.25 & 12.5 & 50 & 27.5 \\
\hline Providencia sp. P8 & 3.13 & 1.56 & 30 & 3.13 & 3.13 & 6.25 & 12.5 & 3.43 \\
\hline $\begin{array}{l}\text { Pseudomonas aeruginosa } \\
\quad \text { IFO } 3445\end{array}$ & 12.5 & 12.5 & $>60$ & 12.5 & 12.5 & 3.13 & 6.25 & 55 \\
\hline P. aeruginosa NCTC 10490 & 12.5 & 25 & $>60$ & 12.5 & 12.5 & 0.78 & 3.13 & 13.8 \\
\hline Serratia marcescens $\mathrm{S} 18^{c}$ & 3.13 & 3.13 & $>60$ & 6.25 & 12.5 & 12.5 & 50 & 27.5 \\
\hline S. marcescens $\mathrm{T} 55^{\circ}$ & 3.13 & 6.25 & $>$ & 12.5 & 12.5 & 12.5 & 50 & 110 \\
\hline
\end{tabular}

Inoculum size: $10^{6}$ cells $/ \mathrm{ml}$.

Medium: (No mark) Heart infusion agar; ${ }^{2}$ Mueller-Hinton agar.

${ }^{b}$ Penicillinase-producer. ${ }^{c}$ Cephalosporinase-producer.

THM: Thienamycin. IPM: Imipenem. CEZ: Cefazolin. ABPC: Ampicillin.

susceptibility, presumably because NS- 5 becomes physico-chemically more labile than PS-5, as is reported for MM 4550 (sulfoxide) ${ }^{9}$. Dimethylation of NS-5 (derivative 6), however, results in diminished antibiotic activity. Phenylacetylation (derivative 7) and phosphorylation (derivative 8) of NS-5 reduce the antibacterial activity against the Gram-negative microbes only. As is observed with NS-5, the introduction of a 4-pyridyl group (derivative 9) improves the antibacterial activity against the Gram-positive pathogens owing to elevated basicity, while its activity falls against the Gram-negative bacteria including the pseudomonads.

Table 3 deals with " $-\mathrm{S}-\mathrm{CH}_{2}-\mathrm{CH}(\mathrm{NHX})$-" as common structure of the C-3 side chain of PS-5. Replacement of the acetamidoethylthio side chain (PS-5; derivative 1) by optically active cysteines (derivatives 10 and 11) leads to the significantly reduced activities against the Gram-positive microbes, while the improved activity against the Gram-negative bacteria is higher with the D-cysteinyl side chain (derivative 11) than with the L-cysteinyl (derivative 10). Accordingly, all the rest derivatives in Table 3 have the amino group in the $(S)$-configuration.

The introduction of a hydroxymethyl group (derivative 12) into NS-5 (derivative 5) results in the 
Table 2. (Continued)

\begin{tabular}{|c|c|c|c|c|c|c|c|}
\hline & \multicolumn{7}{|c|}{ Derivative } \\
\hline & 8 & 9 & THM & IPM & CEZ & $\mathrm{ABPC}$ & $88617^{\mathbf{a}, 22)}$ \\
\hline \multicolumn{8}{|l|}{ Gram-positive bacteria: } \\
\hline Bacillus subtilis ATCC 6633 & 0.10 & 0.03 & 0.024 & 0.006 & 0.10 & $<0.003$ & $<0.006$ \\
\hline $\begin{array}{l}\text { Micrococcus luteus } \\
\text { ATCC } 9341\end{array}$ & 0.10 & 0.008 & 0.024 & 0.012 & 0.78 & $<0.003$ & 0.012 \\
\hline $\begin{array}{l}\text { Staphylococcus aureus } \\
\text { FDA 209P }\end{array}$ & 0.012 & 0.008 & 0.012 & 0.006 & 0.10 & $<0.003$ & $<0.006$ \\
\hline S. aureus Smith & 0.012 & 0.06 & 0.024 & 0.006 & 0.10 & 0.20 & 0.012 \\
\hline S. aureus Russell ${ }^{\mathrm{b}}$ & 0.012 & 0.03 & 0.024 & & 0.10 & 0.05 & \\
\hline S. epidermidis & 0.10 & 0.03 & 0.024 & & 0.20 & $<0.003$ & \\
\hline \multicolumn{8}{|l|}{ Gram-negative bacteria: } \\
\hline Alcaligenes faecalis Al & 3.13 & 0.25 & 0.39 & & 3.13 & 0.10 & 0.39 \\
\hline Citrobacter freundii $\mathrm{GN} 346^{\mathrm{c}}$ & 12.5 & 8.1 & 0.39 & 0.20 & $>400$ & $>100$ & 0.78 \\
\hline Comamonas terrigena B-996 & 0.05 & $<0.008$ & 0.05 & 0.024 & 0.05 & 0.10 & 0.024 \\
\hline Enterobacter aerogenes $\mathrm{E} 19^{\circ}$ & 12.5 & 16.2 & 0.39 & 0.20 & $>400$ & $>100$ & 0.78 \\
\hline E. cloacae $45^{\mathrm{c}}$ & 12.5 & 130 & 0.78 & 0.39 & $>400$ & $>100$ & 1.56 \\
\hline Enterobacter sp. E8 ${ }^{b}$ & 6.25 & 4.1 & 0.39 & & 0.78 & 12.5 & \\
\hline Escherichia coli $\mathrm{K}-12$ & 6.25 & 4.1 & 0.20 & 0.10 & 1.56 & 3.13 & 0.39 \\
\hline E. coli $\mathrm{RGN} 823^{\mathrm{b}}$ & 6.25 & 8.1 & 0.78 & 0.10 & 12.5 & $>100$ & 0.78 \\
\hline Klebsiella pneumoniae $\mathrm{K} 13^{b}$ & 12.5 & 32.4 & 1.56 & 0.10 & 12.5 & $>100$ & 0.39 \\
\hline Proteus mirabilis $\mathrm{P} 6$ & 25 & 4.1 & 3.13 & & 12.5 & 3.13 & \\
\hline P. rettgeri $\mathrm{P} 7^{\mathrm{c}}$ & 12.5 & 4.1 & 1.56 & & 0.78 & 1.56 & \\
\hline P. vulgaris $\mathrm{GN} 76^{\mathrm{c}}$ & 25 & 32.4 & 3.13 & 3.13 & $>400$ & $>100$ & 1.56 \\
\hline Proteus sp. $\mathrm{P} 22^{\mathrm{c}}$ & 25 & 16.2 & 3.13 & & $>400$ & $>100$ & 3.13 \\
\hline Providencia sp. P8 & 6.25 & 1.0 & 0.78 & & 12.5 & 50 & \\
\hline $\begin{array}{l}\text { Pseudomonas aeruginosa } \\
\text { IFO } 3445\end{array}$ & 12.5 & 130 & 0.78 & 3.13 & $>400$ & 12.5 & \\
\hline P. aeruginosa NCTC 10490 & 3.13 & 16.2 & 0.78 & 0.39 & $>400$ & 12.5 & 0.39 \\
\hline Serratia marcescens $\mathrm{S} 18^{\mathrm{c}}$ & 25 & 16.2 & 1.56 & & $>400$ & $>100$ & 0.10 \\
\hline S. marcescens $\mathrm{T} 55^{\mathrm{c}}$ & 25 & 130 & 1.56 & 0.78 & $>400$ & 50 & 1.56 \\
\hline
\end{tabular}

diminished antibacterial activity. Amidation (derivative 13) and pyridylamidation (derivative 14) of the terminal carboxyl in the C-3 side chain of derivative $\mathbf{1 1}$ improves the antibacterial activity against the Gram-positive bacteria, but reduces the activity against the Gram-negative microbes. Dimethylation (derivative 15), acetylation (derivative 16) and iso-nicotinylation (derivative 17) of the free amino group of derivative 11 clearly cause the activity to drop. Coupling of derivative 11 with 6-aminopenicillanate (derivative 18) decreases the antibiotic activity, particularly against the Gram-negative bacteria. Dimethylation of the C-3 side chain at C-11 (derivative 19) also diminishes antibacterial activity.

It is noteworthy that the configuration of the amino group of the C-3 side chain (derivatives 10 and 11) is important not only for expression of antimicrobial activity, but also stabilization to DHP-I (see a separate paper $)^{10)}$.

Table 4 contains the PS-5 derivatives which have " $-\mathrm{S}-\mathrm{CH}_{2}-$ " as common structure of the $\mathrm{C}-3$ side chain. In structural comparison with the C-3 side chain of PS-5, no plausible explanation is available about the good antibacterial activity of derivative $\mathbf{2 0}$ against the Gram-positive test microbes, while its activity against the Gram-negative organisms falls. The introduction of basic groups such as imidazolyl, hydroxypyridyl and aminopyridylcarbamoyl (derivatives 21, 22 and 24) leads to improved antibacterial activity against the Gram-positive pathogens, as is observed above with NS-5 (derivative 5), and to reduced activity against the Gram-negative microorganisms. The other carbapenems (derivatives 23,25 and 26) 
Table 3. Comparative antibacterial activities of PS-5 derivatives (2) MIC $(\mu \mathrm{g} / \mathrm{ml})$.

\begin{tabular}{|c|c|c|c|c|c|c|c|c|c|c|c|c|c|}
\hline & \multicolumn{13}{|c|}{ Derivative } \\
\hline & 10 & 11 & $12^{\mathrm{a}}$ & $13^{\mathrm{a}}$ & $14^{\mathrm{a}}$ & $15^{2}$ & 16 & 17 & 18 & 19 & 1 (PS-5) & 4 & 5 \\
\hline \multicolumn{14}{|l|}{ Gram-positive bacteria: } \\
\hline Bacillus subtilis ATCC 6633 & 0.78 & 0.20 & 0.20 & 0.20 & 0.10 & 0.20 & 0.39 & 0.39 & 0.20 & 0.39 & 0.05 & 0.39 & 0.05 \\
\hline Micrococcus luteus ATCC 9341 & 0.78 & 1.56 & 0.20 & 0.39 & 0.10 & 0.39 & 3.13 & 3.13 & 0.20 & 1.56 & 0.05 & 1.56 & 0.024 \\
\hline Staphylococcus aureus FDA 209P & 0.39 & 0.78 & 0.012 & 0.05 & 0.024 & 0.10 & 3.13 & 3.13 & 0.78 & 0.78 & 0.024 & 0.78 & 0.001 \\
\hline S. aureus Smith & 0.39 & 0.39 & 0.05 & 0.39 & 0.20 & 0.39 & 6.25 & 3.13 & 3.13 & 0.39 & 0.10 & 1.56 & 0.003 \\
\hline S. aureus Russell $^{\mathrm{b}}$ & 0.39 & 0.39 & 0.05 & 0.39 & 0.39 & 0.39 & 6.25 & 6.25 & 1.56 & 0.39 & 0.10 & 1.56 & 0.024 \\
\hline S. epidermidis & 0.78 & 1.56 & 0.10 & 0.39 & 0.39 & 0.39 & 6.25 & 3.13 & 0.78 & 1.56 & 0.20 & 1.56 & 0.05 \\
\hline \multicolumn{14}{|l|}{ Gram-negative bacteria: } \\
\hline Alcaligenes faecalis A1 & 3.13 & 1.56 & 1.56 & 3.13 & 1.56 & 1.56 & 3.13 & 1.56 & 6.25 & 3.13 & 0.39 & 0.78 & 1.56 \\
\hline Citrobacter freundii GN346 & 6.25 & 1.56 & 6.25 & 6.25 & 12.5 & 6.25 & $>100$ & $>100$ & 200 & $>100$ & 3.13 & 25 & 6.25 \\
\hline Comamonas terrigena B-996 & 0.20 & 0.024 & 0.012 & 0.012 & 0.05 & 0.05 & 0.10 & 0.10 & 0.10 & 0.20 & 0.024 & 0.024 & 0.05 \\
\hline Enterobacter aerogenes E19 & 6.25 & 0.39 & 12.5 & 12.5 & 6.25 & 6.25 & 50 & $>100$ & 100 & 100 & 3.13 & 6.25 & 6.25 \\
\hline E. cloacae $45^{\mathrm{c}}$ & 12.5 & 3.13 & 12.5 & 12.5 & 12.5 & 12.5 & 50 & $>100$ & $>200$ & $>100$ & 3.13 & 25 & 12.5 \\
\hline Enterobacter sp. E8 ${ }^{c}$ & 3.13 & 0.05 & 6.25 & 12.5 & 6.25 & 6.25 & 12.5 & 50 & 12.5 & 50 & 3.13 & 3.13 & 6.25 \\
\hline Escherichia coli $\mathrm{K}-12$ & 3.13 & 0.024 & 6.25 & 6.25 & 3.13 & 6.25 & 12.5 & 50 & 6.25 & 50 & 1.56 & 3.13 & 6.25 \\
\hline E. coli $\mathrm{RGN} 823^{\mathrm{b}}$ & 6.25 & 0.05 & 3.13 & 6.25 & 3.13 & 6.25 & 12.5 & 25 & 6.25 & 50 & 3.13 & 6.25 & 3.13 \\
\hline Klebsiella pneumoniae $\mathrm{K} 13^{\mathrm{b}}$ & 12.5 & 0.39 & 12.5 & 12.5 & 12.5 & 6.25 & 100 & $>100$ & 100 & 50 & 3.13 & 6.25 & 6.25 \\
\hline Proteus mirabilis P6 & 25 & 0.78 & 25 & 12.5 & 12.5 & 25 & 25 & 50 & 6.25 & 50 & 6.25 & 6.25 & 12.5 \\
\hline P. rettgeri $\mathrm{P}^{\mathrm{c}}$ & 12.5 & 3.13 & 12.5 & 12.5 & 6.25 & 25 & 25 & 25 & 6.25 & 100 & 3.13 & 3.13 & 12.5 \\
\hline P. vulgaris $\mathrm{GN} 76^{\mathrm{C}}$ & 12.5 & 0.78 & 25 & 25 & 12.5 & 25 & 25 & 50 & 25 & 25 & 6.25 & 6.25 & 12.5 \\
\hline Proteus sp. $\mathrm{P} 22^{\mathrm{C}}$ & 12.5 & 1.56 & 25 & 12.5 & 12.5 & 25 & 25 & 50 & 25 & 50 & 6.25 & 6.25 & 12.5 \\
\hline Providencia sp. P8 & 6.25 & 0.10 & 12.5 & 3.13 & 1.56 & 12.5 & 6.25 & 6.25 & 6.25 & 12.5 & 3.13 & 3.13 & 6.25 \\
\hline Pseudomonas aeruginosa IFO 3445 & 25 & 3.13 & 3.13 & 12.5 & 50 & 25 & $>100$ & $>100$ & 100 & $>100$ & 12.5 & 12.5 & 3.13 \\
\hline P. aeruginosa NCTC 10490 & 25 & 6.25 & 3.13 & 25 & 12.5 & 25 & $>100$ & $>100$ & 100 & $>100$ & 12.5 & 12.5 & 0.78 \\
\hline Serratia marcescens $\mathrm{S} 18^{\circ}$ & 3.13 & 0.39 & 25 & 12.5 & 12.5 & 25 & $>100$ & $>100$ & 50 & $>100$ & 3.13 & 12.5 & 12.5 \\
\hline S. marcescens $\mathrm{T} 55^{\mathrm{c}}$ & 25 & 3.13 & 25 & 12.5 & 12.5 & 25 & $>100$ & $>100$ & 50 & $>100$ & 3.13 & 12.5 & 12.5 \\
\hline
\end{tabular}

Inoculum size: $10^{6}$ cells $/ \mathrm{ml}$.

Medium: (No mark) Heart infusion agar; ${ }^{\mathrm{a}}$ Mueller-Hinton agar.

Penicillinase-producer.

c Cephalosporinase-producer. 
Table 4. Comparative antibacterial activities of PS-5 derivatives (3) MIC $(\mu \mathrm{g} / \mathrm{ml})$.

\begin{tabular}{|c|c|c|c|c|c|c|c|c|c|c|}
\hline & \multicolumn{10}{|c|}{ Derivative } \\
\hline & 20 & 21 & 22 & 23 & 24 & 25 & 26 & 1 (PS-5) & 3 & 4 \\
\hline \multicolumn{11}{|l|}{ Gram-positive bacteria: } \\
\hline Bacillus subtilis ATCC 6633 & $<0.012$ & 0.006 & 0.05 & 3.13 & 0.05 & 0.39 & 1.56 & 0.05 & 0.10 & 0.39 \\
\hline Micrococcus luteus ATCC 9341 & $<0.012$ & 0.006 & 0.05 & 12.5 & 0.012 & 0.39 & 3.13 & 0.05 & 0.10 & 1.56 \\
\hline Staphylococcus aureus FDA 209P & $<0.012$ & 0.0015 & 0.10 & 3.13 & 0.012 & 0.39 & 3.13 & 0.24 & 0.05 & 0.78 \\
\hline S. aureus Smith & $<0.012$ & 0.05 & 0.10 & 1.56 & 0.024 & 1.56 & 1.56 & 0.10 & 0.10 & 1.56 \\
\hline S. aureus Russell ${ }^{\mathrm{b}}$ & $<0.012$ & 0.006 & 0.10 & 3.13 & 0.024 & 0.78 & 3.13 & 0.10 & 0.20 & 1.56 \\
\hline S. epidermidis & $<0.012$ & 0.012 & 0.10 & 6.25 & 0.05 & 0.78 & 3.13 & 0.20 & 0.20 & 1.56 \\
\hline \multicolumn{11}{|l|}{ Gram-negative bacteria: } \\
\hline Alcaligenes faecalis $\mathrm{Al}$ & 6.25 & 0.20 & 0.39 & 3.13 & 0.39 & 6.25 & 3.13 & 0.39 & 1.56 & 0.78 \\
\hline Citrobacter freundii $\mathrm{GN} 346^{\mathrm{c}}$ & 25 & 1.56 & 6.25 & 100 & 12.5 & $>50$ & 50 & 3.13 & 3.13 & 25 \\
\hline Comamonas terrigena B-996 & $<0.012$ & $<0.0008$ & 0.024 & 0.20 & 0.006 & 0.10 & 0.024 & 0.024 & 0.024 & 0.024 \\
\hline Enterobacter aerogenes $\mathrm{E} \mathrm{g}^{\mathrm{c}}$ & 25 & 3.13 & 12.5 & 50 & 25 & $>50$ & 12.5 & 3.13 & 3.13 & 6.25 \\
\hline E. cloacae $45^{\mathrm{c}}$ & 50 & 1.56 & 12.5 & 100 & 25 & $>50$ & 50 & 3.13 & 6.25 & 25 \\
\hline Enterobacter sp. E8 ${ }^{\mathrm{c}}$ & 6.25 & 0.78 & 3.13 & 12.5 & 12.5 & 25 & 6.25 & 3.13 & 3.13 & 31.3 \\
\hline Escherichia coli $\mathrm{K}-12$ & 3.13 & 0.78 & 3.13 & 12.5 & 6.25 & 12.5 & 3.13 & 1.56 & 3.13 & 3.13 \\
\hline E. coli $\mathrm{RGN} 823^{b}$ & 6.25 & 1.56 & 1.56 & 12.5 & 3.13 & $>50$ & 3.13 & 3.13 & 12.5 & 6.25 \\
\hline Klebsiella pneumoniae $\mathrm{K} 13^{\mathrm{b}}$ & 12.5 & 1.56 & 6.25 & 25 & 25 & $>50$ & 25 & 3.13 & 12.5 & 6.25 \\
\hline Proteus mirabilis P6 & 6.25 & 6.25 & 6.25 & 50 & 12.5 & 6.25 & 25 & 6.25 & 12.5 & 6.25 \\
\hline P. retigeri $\mathbf{P} 7^{\mathrm{c}}$ & 3.13 & 1.56 & 1.56 & 25 & 6.25 & 6.25 & 6.25 & 3.13 & 12.5 & 3.13 \\
\hline$P$. vulgaris $\mathrm{GN} 76^{\mathrm{c}}$ & 12.5 & 6.25 & 6.25 & 50 & 12.5 & 50 & 25 & 6.25 & 25 & 6.25 \\
\hline Proteus sp. $\mathrm{P} 22^{\mathrm{c}}$ & 12.5 & 6.25 & 12.5 & 50 & 12.5 & 50 & 25 & 6.25 & 50 & 6.25 \\
\hline Providencia sp. P8 & 1.56 & 1.56 & 1.56 & 12.5 & 3.13 & 6.25 & 3.13 & 3.13 & 3.13 & 3.13 \\
\hline Pseudomonas aeruginosa IFO 3445 & 25 & 6.25 & 12.5 & $>100$ & $>100$ & $>50$ & $>100$ & 12.5 & 12.5 & 12.5 \\
\hline P. aeruginosa NCTC 10490 & 25 & 0.78 & 6.25 & $>100$ & 100 & 25 & $>100$ & 12.5 & 12.5 & 12.5 \\
\hline Serratia marcescens $\mathrm{S} 18^{c}$ & 12.5 & 1.56 & 6.25 & 25 & 25 & $>50$ & 12.5 & 3.13 & 6.25 & 12.5 \\
\hline S. marcescens $\mathrm{T} 55^{\mathrm{c}}$ & 50 & 1.56 & 12.5 & 50 & 100 & $>50$ & 25 & 3.13 & 12.5 & 12.5 \\
\hline
\end{tabular}

Inoculum size: $10^{6}$ cells $/ \mathrm{ml}$

Medium: Heart infusion agar.

benicillinase-producer.

c Cephalosporinase-producer. 
Table 5. Comparative antibacterial activities of PS-5 derivatives (4) MIC $(\mu \mathrm{g} / \mathrm{ml})$.

\begin{tabular}{|c|c|c|c|c|c|c|c|c|c|c|c|c|c|}
\hline & \multicolumn{13}{|c|}{ Derivative } \\
\hline & 27 & 28 & 29 & 30 & 31 & 32 & 33 & 34 & 35 & 1 (PS-5) & 2 & 5 & 9 \\
\hline \multicolumn{14}{|l|}{ Gram-positive bacteria: } \\
\hline Bacillus subtilis ATCC 6633 & 0.09 & 0.07 & 0.012 & $<0.007$ & 0.05 & $<0.012$ & 0.024 & 0.25 & 0.39 & 0.05 & 3.75 & 0.05 & 0.03 \\
\hline Micrococcus luteus ATCC 9341 & $<0.01$ & $<0.01$ & $<0.001$ & $<0.007$ & 0.0015 & $<0.012$ & 0.024 & 0.12 & 0.10 & 0.05 & 1.88 & 0.024 & $<0.008$ \\
\hline $\begin{array}{l}\text { Staphylococcus aureus } \\
\text { FDA 209P }\end{array}$ & $<0.01$ & $<0.01$ & 0.006 & $<0.007$ & 0.05 & $<0.012$ & 0.024 & 0.12 & 0.39 & 0.024 & 0.24 & 0.001 & $<0.008$ \\
\hline S. aureus Smith & 0.04 & 0.10 & 0.012 & $<0.007$ & 0.10 & 0.024 & 0.05 & 0.25 & 0.78 & 0.10 & & 0.003 & 0.06 \\
\hline S. aureus Russell $^{\mathrm{b}}$ & $<0.01$ & $<0.01$ & 0.012 & $<0.007$ & 0.05 & $<0.012$ & 0.05 & 0.25 & 0.78 & 0.10 & & 0.024 & 0.03 \\
\hline S. epidermidis & 0.04 & $<0.01$ & 0.012 & $<0.007$ & 0.05 & 0.024 & 0.05 & 0.25 & 0.78 & 0.20 & 0.12 & 0.05 & 0.03 \\
\hline \multicolumn{14}{|l|}{ Gram-negative bacteria: } \\
\hline Alcaligenes faecalis $\mathrm{Al}$ & 5.6 & 4.7 & 0.10 & $<0.007$ & 0.39 & 0.20 & 0.20 & 63.5 & 6.25 & 0.39 & 15.0 & 1.56 & 0.25 \\
\hline Citrobacter freundii $\mathrm{GN} 346^{\mathrm{c}}$ & 180 & 150 & 25 & 29.5 & 25 & 25 & 12.5 & $>127$ & $>50$ & 3.13 & $>60$ & 6.25 & 8.1 \\
\hline Comamonas terrigena B-996 & $<0.01$ & $<0.01$ & 0.003 & $<0.007$ & 0.003 & $<0.012$ & 0.006 & 0.5 & 0.10 & 0.024 & 0.24 & 0.05 & $<0.008$ \\
\hline Enterobacter aerogenes $\mathrm{E} 19^{c}$ & $>180$ & 150 & 25 & 7.4 & 50 & 12.5 & 6.25 & $>127$ & $>50$ & 3.13 & $>60$ & 6.25 & 16.2 \\
\hline E. cloacae $45^{\circ}$ & $>180$ & 150 & 50 & 29.5 & 50 & 25 & 50 & $>127$ & $>50$ & 3.13 & & 12.5 & 130 \\
\hline Enterobacter sp. E8 ${ }^{c}$ & $>180$ & 75 & 12.5 & 0.46 & 12.5 & 3.13 & 12.5 & 127 & $>50$ & 3.13 & $>60$ & 6.25 & 4.1 \\
\hline Escherichia coli $\mathrm{K}-12$ & 180 & 37.5 & 6.25 & 0.92 & 6.25 & 1.56 & 6.25 & 63.5 & $>50$ & 1.56 & $>60$ & 6.25 & 4.1 \\
\hline E. coli $\mathrm{RGN} 823^{\mathrm{b}}$ & 180 & 37.5 & 6.25 & 14.8 & 3.13 & 3.13 & 3.13 & 127 & $>50$ & 3.13 & $>60$ & 3.13 & 8.1 \\
\hline Klebsiella pneumoniae $\mathrm{K} 13^{\mathrm{b}}$ & $>180$ & $>150$ & 25 & 14.8 & 25 & 12.5 & 25 & $>127$ & $>50$ & 3.13 & $>60$ & 6.25 & 32.4 \\
\hline Proteus mirabilis $\mathrm{P} 6$ & 45 & 75 & 3.13 & 1.8 & 12.5 & 3.13 & 6.25 & $>127$ & $>50$ & 6.25 & $>60$ & 12.5 & 4.1 \\
\hline P. rettgeri $\mathrm{P} 7^{\mathrm{c}}$ & 180 & 75 & 6.25 & 1.8 & 3.13 & 3.13 & 3.13 & 63.5 & $>50$ & 3.13 & $>60$ & 12.5 & 4.1 \\
\hline P. vulgaris $\mathrm{GN} 76^{\mathrm{c}}$ & 180 & 150 & 12.5 & 29.5 & 12.5 & 6.25 & 12.5 & $>127$ & $>50$ & 6.25 & $>60$ & 12.5 & 32.4 \\
\hline Proteus sp. $\mathrm{P} 22^{\mathrm{c}}$ & 90 & 75 & 6.25 & 29.5 & 25 & 12.5 & 25 & $>127$ & $>50$ & 6.25 & $>60$ & 12.5 & 16.2 \\
\hline Providencia sp. P8 & 180 & 18.8 & 1.56 & 0.92 & 3.13 & 0.78 & 3.13 & 127 & $>50$ & 3.13 & 30 & 6.25 & 1.0 \\
\hline $\begin{array}{l}\text { Pseudomonas aeruginosa } \\
\text { IFO } 3445\end{array}$ & 180 & 18.8 & 12.5 & 0.92 & 25 & 12.5 & 25 & $>127$ & $>50$ & 12.5 & $>60$ & 3.13 & 130 \\
\hline P. aeruginosa NCTC 10490 & 22.5 & 4.7 & 25 & 0.92 & 6.25 & 12.5 & 6.25 & 63.5 & $>50$ & 12.5 & $>60$ & 0.78 & 16.2 \\
\hline Serratia marcescens $\mathrm{S} 18^{\circ}$ & $>180$ & 75 & 12.5 & 29.5 & 25 & 12.5 & 50 & $>127$ & $>50$ & 3.13 & $>60$ & 12.5 & 16.2 \\
\hline S. marcescens $\mathrm{T} 55^{\mathrm{c}}$ & $>180$ & 150 & 25 & 29.5 & 25 & 25 & 25 & $>127$ & $>50$ & 3.13 & & 12.5 & 130 \\
\hline
\end{tabular}

Inoculum size: $10^{6}$ cells $/ \mathrm{ml}$.

Medium: Heart infusion agar.

b Penicillinase-producer.

c Cephalosporinase-producer. 
show the significantly decreased antibacterial activities against the test microbes.

Table 5 exhibits the antibacterial activities of the carbapenem derivatives which are collectively included in the group having no alkyl linkage between the sulfur atom and the substituents in the C-3 side chain. It is interesting to note that this type of the $\mathrm{C}-3$ side chain modification significantly reduces the antibacterial activity against the Gram-negative microbes only, which seems to indicate that a short alkyl linkage between the sulfur atom and the substituents is necessary for expression of the antibacterial activity against the Gram-negative pathogens, whereas the antibacterial activity against the Gram-positive microbes is not affected by its absence.

\section{Antibacterial Activity against $\beta$-Lactamase-producing Bacteria}

PS-5 is resistant to almost all the $\beta$-lactamases known in the literature excluding several metal-containing ones. Furthermore, it inactivates them, leading to strong synergistic antimicrobial activity ${ }^{1)}$ with the penicillins and cephalosporins. All the naturally-occurring carbapenem compounds including PS-5 and thienamycin, on the other hand, are susceptible in vivo and in vitro to DHP-I by the same mechanism as is observed in the reaction of penicillins and cephalosporins with $\beta$-lactamase ${ }^{11}$, while DHP-I attacks no penicillins and cephalosporins at all. Accordingly, it is important to examine the influence of chemically modified C-3 side chains on $\beta$-lactamase and DHP-I susceptibilities to see if they differ from those having the acetamidoethylthio group in this position.

The antibacterial activities of carbapenem, penicillin and cephalosporin derivatives on $\beta$-lactamaseproducing microorganisms largely depends on the $\beta$-lactamase susceptibilities, $\beta$-lactamase-inactivating activities, and cell wall and membrane permeability. Except for Bacillus cereus type II $\beta$-lactamase ${ }^{12)}$ and Pseudomonas maltophilia $\beta$-lactamase ${ }^{13}$, no enzymes are known to inactivate carbapenems. Accordingly it seemed acceptable to postulate that MICs were a useful indicator for $\beta$-lactamase susceptibility. In this paper, the effects of the $\mathrm{C}-3$ side chain modification on $\beta$-lactamases were indirectly examined by the antibacterial activity against the $\beta$-lactamase-producing Gram-negative microorganisms. In a subsequent paper, the $\beta$-lactamase-susceptibility and $\beta$-lactamase-inhibitory activity of these and related carbapenem derivatives will be studied in vitro by purified $\beta$-lactamase preparations.

To antibacterial activity of PS-5 against $\beta$-lactamase-producing Gram-positive bacteria except $B$. cereus is not influenced by the introduction of a variety of side chains at $C-3$ (Staphylococcus aureus Russell in Tables 2 5 and unpublished results).

As is reported by SAWAI et al. ${ }^{14)}$, the $\beta$-lactamase-susceptibility and the cell wall and membrane permeability of penicillins and cephalosporins are key factors in expression of their antibiotic activity against $\beta$-lactamase-producing Gram-negative microbes. PS-5 (parent compound) shows strong antibacterial activity against the $\beta$-lactamase-producing Gram-negative bacteria (Table 2), suggesting seemingly complete resistance of PS-5 to these $\beta$-lactamases in vitro. The C-6 ethyl and C-3 acetamidoethylthio side chains and the stereochemistry at C-6 of PS-5 are known to be very important for expression of its antibacterial activity against Gram-positive and Gram-negative bacteria.

An examination of Tables 2 5 reveals that the Enterobacter, Proteus, Pseudomonas and Serratia strains are significantly responsive to the chemical modification of the C-3 side chain of PS-5. For example, in the antimicrobial activity against the 3 Enterobacter strains, derivatives $\mathbf{1 1}$ and $\mathbf{2 1}$ seem to differ from derivatives $4,7,10,18,20,22,23,26,29,30,31,32$ and 33. In particular, compared with the acetamidoethylthio side chain of the parent compound, only the D-cysteinyl (derivative 11) and imidazolyl 
(derivative 21) groups increase the specific antibacterial potencies against Enterobacter cloacae 45 and Enterobacter sp. E8. In a similar context, derivatives 11, 30 and $\mathbf{3 2}$ may be different from derivatives 7 , $8,22,25,27,29,31$ and 33 in the pattern of influence of the side chain modification on the antibacterial activity against the 4 Proteus species. Synergism of PS-5 with penicillins and cephalosporins in their antibacterial activity against Proteus vulgaris GN76 was previously reported."

The two strains of $P$. aeruginosa show different responses to the modified C-3 side chains (derivatives $5,7,14,21,27,28,31$ and 33), presumably indicating that the $\beta$-lactamases involved may have distinct substrate profiles. The same observation as above is also seen for derivatives $7,10,11,20$ and 24 against the two strains of Serratia marcescens.

PS-5 is a potent inhibitor of a variety of $\beta$-lactamases ${ }^{15,16)}$, so it seemed reasonable to assume that binding of PS-5 with 6-aminopenicillanate (6-APA) and 7-aminocephalosporanate (7-ACA) with a covalent bond might protect the penicillin and cephalosporin from $\beta$-lactamase attack by virtue of the carbapenem. Contrary to the expectation, however, the introduction of PS-5 to 6-APA (derivatives 18 and 25$)^{17)}$ and 7-ACA (derivative 25) seems to result in rather increased sensitivity of penicillin and cephalosporin to $\beta$-lactamases.

\section{Experimental}

Preparation of Antibiotics

PS-5 (sodium salt) was obtained by fermentation as detailed in a previous paper ${ }^{18)}$. Derivative 5 (NS-5) was prepared from PS-5 by microbial deacetylation ${ }^{19)}$. Thirty-three PS-5 derivatives with modified C-3 side chains were synthesized by the sulfoxide method through Route A or B (Fig. 2). More particularly, derivatives $21 \sim 26$ and 31 were prepared through Route B, and the other derivatives through Route A. Of these derivatives, $2 \sim 6,9,21,22$ and $27 \sim 34$ were described in a previous report $^{8)}$. Thienamycin $(\mathrm{THM})^{20)}$ was produced by fermentation; and imipenem (IPM) ${ }^{21)}$ and $88617^{22)}$ were synthesized according to reported procedures. Cefazolin (CEZ) and ampicillin (ABPC) were purchased from Fujisawa Pharmaceuticals Co., Ltd. and Toyo Jozo Co., Ltd., respectively.

\section{Antibacterial Evaluation}

Susceptibility testing was performed by the standard agar dilution technique ${ }^{23)}$ using Mueller-Hinton agar and Heart infusion agar (Difco). Overnight cultures of test organisms were diluted in saline. Final inocula of approximately $10^{6} \mathrm{cell} / \mathrm{s} / \mathrm{ml}$ were applied on agar medium by a multipoint spot inoculator. Agar plates were examined after 18 hours of incubation at $35^{\circ} \mathrm{C}$.

\section{General Methodology}

UV and IR spectra were recorded on a Hitachi 200-20 and a Hitachi 260-30 spectrophotometer, respectively. NMR spectra were obtained in $\mathrm{CDCl}_{3}$ with a Varian EM-390 or a Jeol PS-100 spectrometer, using TMS as internal standard, unless otherwise stated. MS data were obtained with Hitachi EM- 80 and RMU-7 mass spectrometers. Specific rotations were measured with a Jasco DIP-181 digital polarimeter. Pre-coated silica gel plates $\mathrm{F}_{254}$ and Silica gel 60 (70 300 mesh, E. Merck, Darmstadt) were used for TLC and column chromatography, respectively. All carbapenem $p$-nitrobenzyl esters were deprotected by hydrogenation and chromatographed on a column of QAE-Sephadex A-25 or Diaion CHP-20AG followed by freeze-drying to yield corresponding carbapenem derivatives.

\section{Chemical Derivation}

$p$-Nitrobenzyl 3-(2-Phenylacetylaminoethyl)thio-6-ethyl-7-oxo-1-azabicyclo[3.2.0]hept-2-ene-2-carboxylate (Protected Derivative 7; A Typical Example of Derivation Through Route A): To a solution of $150 \mathrm{mg}(0.334 \mathrm{mmol})$ of PS-5 $p$-nitrobenzyl ester sulfoxide in $40 \mathrm{ml}$ of DMF were dropwise added $51 \mu 1$ $(0.36 \mathrm{mmol})$ of triethylamine and $72 \mathrm{mg}(0.369 \mathrm{mmol})$ of $N$-phenylacetylcysteamine in $1 \mathrm{ml}$ of DMF at $-50^{\circ} \mathrm{C}$ under stirring. After agitation for 1 hour at $-50^{\circ} \mathrm{C}$, the reaction mixture was poured into $80 \mathrm{ml}$ 
of benzene and washed three times with $0.1 \mathrm{M}$ phosphate buffer, $\mathrm{pH} 6.8$. The organic layer was separated, dried over anhydrous sodium sulfate and filtered. The filtrate was concentrated to dryness under reduced pressure to give a pale-yellow oily product. The product was dissolved in a small volume of methylene chloride and passed through a column of silica gel $(20 \mathrm{~g})$ which had been wetted with a solvent mixture of benzene and acetone $(1: 1)$. The product was developed with the same solvent system. From the eluate $134 \mathrm{mg}$ of the title compound ( $79 \%$ yield) was recovered. On a silica gel TLC plate this derivative showed an $\mathrm{Rf}$ value of 0.66 with a solvent system of benzene - acetone $(1: 2)$. [ $\alpha]_{\mathrm{D}}^{22} 50.4^{\circ}\left(c 0.8\right.$, THF); UV $\lambda_{\max }^{\mathrm{THF}}$ $\mathrm{nm}(\varepsilon) 268(9,800), 321(11,300) ; \mathrm{IR} v_{\max }\left(\mathrm{CHCl}_{3}\right) \mathrm{cm}^{-1} 1775$ ( $\beta$-lactam), 1700 (ester); ${ }^{1} \mathrm{H}$ NMR $\left(\mathrm{CDCl}_{3}\right)$ $\delta 1.07\left(3 \mathrm{H}, \mathrm{t}, J=7.2 \mathrm{~Hz}, \mathrm{CH}_{2} \mathrm{CH}_{3}\right), 1.70 \sim 2.00\left(2 \mathrm{H}, \mathrm{m},-\mathrm{CH}_{2} \mathrm{CH}_{3}\right), 2.80 \sim 3.55(7 \mathrm{H}, \mathrm{m}, 4-\mathrm{H} \times 2,6-\mathrm{H}$, $\left.\mathrm{SCH}_{2} \mathrm{CH}_{2} \mathrm{~N}\right), 3.56\left(2 \mathrm{H}, \mathrm{s}, \mathrm{Ar}-\mathrm{C} \mathrm{H}_{2} \mathrm{CO}\right), 3.97(1 \mathrm{H}, \mathrm{dt}, J=3$ and $9 \mathrm{~Hz}, 5-\mathrm{H}), 5.22(1 \mathrm{H}, \mathrm{d}, J=14 \mathrm{~Hz}, \mathrm{CHH}-\mathrm{Ar})$, $5.51(1 \mathrm{H}, \mathrm{d}, J=14 \mathrm{~Hz}, \mathrm{CH} H-\mathrm{Ar}), 5.82(1 \mathrm{H}, \mathrm{m}, \mathrm{NH}), 7.30(5 \mathrm{H}, \mathrm{s}, \mathrm{Ar}), 7.65(2 \mathrm{H}, \mathrm{d}, J=9 \mathrm{~Hz}, \mathrm{Ar}), 8.21$ $(2 \mathrm{H}, \mathrm{d}, J=9 \mathrm{~Hz}, \mathrm{Ar})$; MS $(\mathrm{m} / \mathrm{z}) 509\left(\mathrm{M}^{+}\right), 439\left(\mathrm{M}^{+}-\mathrm{EtCH}=\mathrm{C}=\mathrm{O}\right)$.

Sodium 3-(2-Phenylacetylaminoethyl)thio-6-ethyl-7-oxo-1-azabicyclo[3.2.0]hept-2-ene-2-carboxylate (Derivative 7): $p$-Nitrobenzyl 3-(2-phenylacetylaminoethyl)thio-6-ethyl-7-oxo-1-azabicyclo[3.2.0]hept2-ene-2-carboxylate $(120 \mathrm{mg}$ ) was dissolved in a solvent mixture of $10.2 \mathrm{ml}$ of THF and $9.4 \mathrm{ml}$ of $0.1 \mathrm{M}$

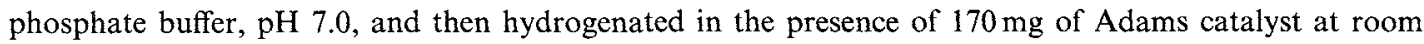
temperature for 5 hours in a Paar apparatus (hydrogen pressure $4 \mathrm{~kg} / \mathrm{cm}^{2}$ ). The catalyst was removed by filtration and washed with $0.01 \mathrm{~m}$ phosphate buffer, $\mathrm{pH} 6.8$. The filtrate and the phosphate wash were combined. The solution was applied on a column of QAE-Sephadex A-25 $(1.1 \times 20 \mathrm{~cm})$ and developed with a linear concentration gradient of sodium chloride in $0.01 \mathrm{~m}$ phosphate buffer, $\mathrm{pH} 6.8$, from 0 to $0.4 \mathrm{M}$. Each eluate fraction was monitored with a spectrophotometer and fractions having an absorption maximum at $300 \mathrm{~nm}$ were combined. After $2 \%$ sodium chloride was added, the solution was charged on a column of Diaion CHP-20AG $(1.1 \times 20 \mathrm{~cm})$. Elution was carried out with a linear concentration gradient of acetone in water from 0 to $30 \%$ (total eluant $200 \mathrm{ml}$ ). Eluate fractions possessing a UV absorption maximum at $300 \mathrm{~nm}$ were collected and freeze-dried to give $31.8 \mathrm{mg}$ of the target derivative (yield $34 \%$ ).

$\mathrm{UV} \lambda_{\max }^{\mathrm{H}_{2} \mathrm{O}} \mathrm{nm}(\varepsilon) 301(4,800) ;{ }^{1} \mathrm{H}$ NMR $\left(\mathrm{D}_{2} \mathrm{O}\right) \delta 1.02\left(3 \mathrm{H}, \mathrm{t}, J=7.5 \mathrm{~Hz}, \mathrm{CH}_{2} \mathrm{CH}_{3}\right), 1.80(2 \mathrm{H}, \mathrm{m}$, $\left.-\mathrm{CH}_{2} \mathrm{CH}_{3}\right), 2.7 \sim 3.35\left(5 \mathrm{H}, \mathrm{m}, 4-\mathrm{H} \times 2,6-\mathrm{H}, \mathrm{NHCH}_{2}-\right), 3.43\left(2 \mathrm{H}, \mathrm{t}, J=6 \mathrm{~Hz},-\mathrm{SCH} H_{2}-\right), 3.62(2 \mathrm{H}, \mathrm{s}$, $\left.\mathrm{Ar}-\mathrm{CH}_{2} \mathrm{CO}\right), 3.90(1 \mathrm{H}, \mathrm{m}, 5-\mathrm{H}), 7.28(5 \mathrm{H}, \mathrm{s}, \mathrm{Ar})$.

$p$-Nitrobenzyl 6-Ethyl-3-[2-(di-p-nitrobenzyloxyphosphoryl)aminoethyl]thio-7-oxo-1-azabicyclo[3.2.0] hept-2-ene-2-carboxylate (Protected Derivative 8): Cysteamine (76.5 $\mathrm{mg}$ ) was dissolved in $3 \mathrm{ml}$ of chloroform and cooled to $-20^{\circ} \mathrm{C}$. A solution of $297 \mathrm{mg}$ of PS-5 p-nitrobenzyl ester $S$-oxide in $20 \mathrm{ml}$ of DMF was added to the cysteamine solution under stirring. Triethylamine $(369 \mu \mathrm{l})$ and then a solution of $511 \mathrm{mg}$ of di-p-nitrobenzyloxyphosphoryl chloride in $2 \mathrm{ml}$ of DMF were added dropwise to the said reaction mixture at $-20^{\circ} \mathrm{C}$. After the same work-up as described for derivative 7 , the crude product was subjected to purification by silica gel column chromatography using a solvent system of benzene and acetone $(2: 1)$. By silica gel TLC monitoring with a developing solvent mixture of benzene and acetone $(1: 2)$, eluate fractions were collected which contained a UV-absorbing compound at $\mathrm{Rf} 0.74$. The evaporation of the solvent under reduced pressure resulted in $122.7 \mathrm{mg}$ of the title product (yield $25 \%$ ). $[\alpha]_{\mathrm{D}}^{24} 37.8^{\circ}(c 1.0, \mathrm{THF}) ; \mathrm{UV} \lambda_{\max }^{\mathrm{THF}} \mathrm{nm}(\varepsilon) 268(31,000), 318(15,300) ; \mathrm{IR} v_{\max }\left(\mathrm{CHCl}_{3}\right) \mathrm{cm}^{-1} 1772(\beta$-lactam), 1708 (ester); ${ }^{1} \mathrm{H}$ NMR $\left(\mathrm{CDCl}_{3}\right) \delta 1.05\left(3 \mathrm{H}, \mathrm{t}, J=7.5 \mathrm{~Hz}, \mathrm{CH}_{2} \mathrm{CH}_{3}\right), 1.50 \sim 2.10\left(2 \mathrm{H}, \mathrm{m}, \mathrm{CH}_{2} \mathrm{CH}_{3}\right)$, $2.70 \sim 3.40\left(7 \mathrm{H}, \mathrm{m}, 4-\mathrm{H} \times 2,6-\mathrm{H},-\mathrm{SCH}_{2} \mathrm{CH}_{2}\right), 3.90(1 \mathrm{H}, \mathrm{dt}, J=3$ and $9 \mathrm{~Hz}, 5-\mathrm{H}), 5.12(4 \mathrm{H}, \mathrm{d}, J=8 \mathrm{~Hz}$, $\left.\mathrm{O}=\mathrm{P}-\mathrm{OCH} \mathrm{H}_{2}-\mathrm{Ar} \times 2\right), 5.20(1 \mathrm{H}, \mathrm{d}, J=14 \mathrm{~Hz}, \mathrm{COOC} H \mathrm{H}-\mathrm{Ar}), 5.50(1 \mathrm{H}, \mathrm{d}, J=14 \mathrm{~Hz}, \mathrm{COOCH} H-\mathrm{Ar}), 7.51$ $(4 \mathrm{H}, \mathrm{d}, J=9 \mathrm{~Hz}, \mathrm{Ar}), 7.66(2 \mathrm{H}, \mathrm{d}, J=9 \mathrm{~Hz}, \mathrm{Ar}), 8.21(6 \mathrm{H}, \mathrm{d}, J=9 \mathrm{~Hz}, \mathrm{Ar})$.

Trisodium 6-Ethyl-3-(2-phosphonatoaminoethyl)thio-7-oxo-1-azabicyclo[3.2.0]hept-2-ene-2-carboxylate (Derivative 8): Derivative 8 was prepared in a manner similar to derivative $7 .{ }^{1} \mathrm{H}$ NMR $\left(\mathrm{D}_{2} \mathrm{O}\right.$, external standard TMS) $\delta 1.46\left(3 \mathrm{H}, \mathrm{t}, J=7.5 \mathrm{~Hz}, \mathrm{CH}_{2} \mathrm{CH}_{3}\right), 1.90 \sim 2.40\left(2 \mathrm{H}, \mathrm{m}, \mathrm{CH}_{2} \mathrm{CH}_{3}\right), 3.25 \sim 4.0$ $\left(7 \mathrm{H}, \mathrm{m}, 4-\mathrm{H} \times 2,6-\mathrm{H}, \mathrm{SCH}_{2} \mathrm{CH}_{2} \mathrm{~N}\right), 4.50(1 \mathrm{H}, \mathrm{dt}, J=3$ and $9 \mathrm{~Hz}, 5-\mathrm{H})$.

$p$-Nitrobenzyl 6-Ethyl-3-[(2R)-2-amino-2-p-nitrobenzyloxycarbonyl]ethylthio-7-oxo-1-azabicyclo[3.2.0]hept-2-ene-carboxylate (Protected Derivative 10): IR $v_{\max }\left(\mathrm{CHCl}_{3}\right) \mathrm{cm}^{-1} 1775$ ( $\beta$-lactam), 1740 (ester); ${ }^{1} \mathrm{H}$ NMR $\left(\mathrm{CDCl}_{3}\right) \delta 1.03\left(3 \mathrm{H}, \mathrm{t}, J=6.9 \mathrm{~Hz}, \mathrm{CH}_{2} \mathrm{CH}_{3}\right), 1.83\left(2 \mathrm{H}, \mathrm{m}, \mathrm{CH}_{2} \mathrm{CH}_{3}\right), 2.32(2 \mathrm{H}, \mathrm{br}$, $\left.\mathrm{NH}_{2}\right), 2.76 \sim 3.53\left(5 \mathrm{H}, \mathrm{m}, 4-\mathrm{H} \times 2,6-\mathrm{H}, \mathrm{l}^{\prime}-\mathrm{H} \times 2\right), 3.67 \sim 4.08\left(2 \mathrm{H}, \mathrm{m}, 5-\mathrm{H}, 2^{\prime}-\mathrm{H}\right), 5.15(1 \mathrm{H}, \mathrm{d}, J=14.5 \mathrm{~Hz}$, $\mathrm{C} H \mathrm{H}-\mathrm{Ar}), 5.24\left(2 \mathrm{H}, \mathrm{s}, \mathrm{CH}_{2}\right.$-Ar $), 5.48(1 \mathrm{H}, \mathrm{d}, J=14.5 \mathrm{~Hz}, \mathrm{CH} H-\mathrm{Ar}), 7.49(2 \mathrm{H}, \mathrm{d}, J=8.5 \mathrm{~Hz}, \mathrm{Ar}), 7.62$ $(2 \mathrm{H}, \mathrm{d}, J=8.5 \mathrm{~Hz}, \mathrm{Ar}), 8.18(4 \mathrm{H}, \mathrm{d}, J=8.5 \mathrm{~Hz}, \mathrm{Ar})$. 
Sodium 6-Ethyl-3-[(2R)-2-amino-2-carboxy]ethylthio-7-oxo-1-azabicyclo[3.2.0]hept-2-ene-2-carboxylate (Derivative 10): UV $\lambda_{\max } \mathrm{nm}(\varepsilon) 298 ;{ }^{1} \mathrm{H}$ NMR $\left(\mathrm{D}_{2} \mathrm{O}\right.$, external standard TMS) $\delta 1.43(3 \mathrm{H}, \mathrm{t}$, $\left.J=7.5 \mathrm{~Hz}, \mathrm{CH}_{2} \mathrm{CH}_{3}\right), 2.19\left(2 \mathrm{H}, \mathrm{m}, \mathrm{CH}_{2} \mathrm{CH}_{3}\right), 3.30 \sim 4.10\left(5 \mathrm{H}, \mathrm{m}, 4-\mathrm{H} \times 2,6-\mathrm{H}, \mathrm{SCH}_{2}-\right), 4.15 \sim 4.72(2 \mathrm{H}$, $\left.\mathrm{m}, 5-\mathrm{H}, 2^{\prime}-\mathrm{H}\right)$.

Sodium 6-Ethyl-3-[(2S)-2-amino-2-carboxy]ethylthio-7-oxo-1-azabicyclo[3.2.0]hept-2-ene-2-carboxylate (Derivative 11): UV $\lambda_{\max } \mathrm{nm}(\varepsilon) 298.5\left(7,900\right.$ ) (in $0.01 \mathrm{~m}$ phosphate buffer, $\mathrm{pH} 7.5$ ); ${ }^{1} \mathrm{H}$ NMR ( $\mathrm{D}_{2} \mathrm{O}$, external standard TMS) $\delta 1.46\left(3 \mathrm{H}, \mathrm{t}, J=7.5 \mathrm{~Hz}, \mathrm{CH}_{2} \mathrm{CH}_{3}\right), 2.0 \sim 2.5\left(2 \mathrm{H}, \mathrm{m},-\mathrm{CH}_{2} \mathrm{CH}_{3}\right), 3.4 \sim 4.1$ $\left(5 \mathrm{H}, \mathrm{m}, 4-\mathrm{H} \times 2,6-\mathrm{H}, 1^{\prime}-\mathrm{H} \times 2\right), 4.34\left(1 \mathrm{H}, \mathrm{dd}, J=4\right.$ and $\left.7.5 \mathrm{~Hz}, 2^{\prime}-\mathrm{H}\right), 4.49(1 \mathrm{H}, \mathrm{dt}, J=3$ and $9 \mathrm{~Hz}, 5-\mathrm{H})$.

$p$-Nitrobenzyl 3-[(2S)-3-Hydroxy-2-p-nitrobenzyloxycarbonylamino]propylthio-7-oxo-1-azabicyclo[3.2.0]hept-2-ene-2-carboxylate (Protected Derivative 12): Rf (silica gel TLC): 0.34 (benzene-acetone, $3: 1) ;[\alpha]_{\mathrm{D}}^{22} 89.5^{\circ}$ (c 1.0, THF); UV $\lambda_{\max }^{\text {THF }} \mathrm{nm}(\varepsilon) 268(20,300), 320.5(12,700) ;$ IR $v_{\max }(\mathrm{KBr}) \mathrm{cm}^{-1} 1765$ ( $\beta$-lactam), 1720 (ester), 1690 (urethane); ${ }^{1} \mathrm{H}$ NMR (DMSO- $\left.d_{6}\right) \delta 0.96\left(3 \mathrm{H}, \mathrm{t}, J=7.5 \mathrm{~Hz}, \mathrm{CH}_{2} \mathrm{CH}_{3}\right), 1.72$ $\left(2 \mathrm{H}, \mathrm{m},-\mathrm{CH}_{2} \mathrm{CH}_{3}\right), 2.8 \sim 3.9\left(8 \mathrm{H}, \mathrm{m}, 4-\mathrm{H} \times 2,6-\mathrm{H}, \mathrm{SCH}_{2} \mathrm{CHCH}_{2} \mathrm{O}\right), 3.93(1 \mathrm{H}, \mathrm{dt}, J=3$ and $9 \mathrm{~Hz}, 5-\mathrm{H})$, $4.88(1 \mathrm{H}, \mathrm{t}, J=5.5 \mathrm{~Hz},-\mathrm{OH}), 5.17\left(2 \mathrm{H}, \mathrm{s}, \mathrm{OCH} \mathrm{H}_{2} \mathrm{Ar}\right), 5.25(1 \mathrm{H}, \mathrm{d}, J=14.5 \mathrm{~Hz}, \mathrm{OC} H \mathrm{H}-\mathrm{Ar}), 5.47(1 \mathrm{H}, \mathrm{d}$, $J=14.5 \mathrm{~Hz}, \mathrm{OCH} H-\mathrm{Ar}), 7.4(1 \mathrm{H}, \mathrm{d}, J=8 \mathrm{~Hz}, \mathrm{NH}), 7.56(2 \mathrm{H}, \mathrm{d}, J=9 \mathrm{~Hz}, \mathrm{Ar}), 7.68(2 \mathrm{H}, \mathrm{d}, J=9 \mathrm{~Hz}, \mathrm{Ar})$, $8.17(4 \mathrm{H}, \mathrm{d}, J=9 \mathrm{~Hz}, \mathrm{Ar})$, MS $(\mathrm{m} / \mathrm{z}) 600\left(\mathrm{M}^{+}\right), 530\left(\mathrm{M}^{+}-\mathrm{CH}_{3} \mathrm{CH}_{2} \mathrm{C}=\mathrm{C}=\mathrm{O}\right)$.

3-[(2S)-2-Amino-3-hydroxy] ethylthio-6-ethyl-7-oxo-1-azabicyclo[3.2.0]hept-2-ene-2-carboxylic Acid (Derivative 12): UV $\lambda_{\max } \mathrm{nm}(\varepsilon) 300(6,600)$ (in $0.01 \mathrm{M}$ phosphate buffer, $\left.\mathrm{pH} 7.0\right) ;{ }^{1} \mathrm{H}$ NMR $\left(\mathrm{D}_{2} \mathrm{O}\right)$ $\delta 0.97\left(3 \mathrm{H}, \mathrm{t}, J=7.5 \mathrm{~Hz},-\mathrm{CH}_{2} \mathrm{CH}_{3}\right), 1.4 \sim 1.9\left(2 \mathrm{H}, \mathrm{m},-\mathrm{CH}_{2} \mathrm{CH}_{3}\right), 2.6 \sim 4.1(9 \mathrm{H}, \mathrm{m}, 4-\mathrm{H} \times 2,5-\mathrm{H}, 6-\mathrm{H}$, $\left.\mathrm{SCH}_{2} \mathrm{CHCH}_{2} \mathrm{O}\right)$.

$p$-Nitrobenzyl 6-Ethyl-3-[(2S)-2-carbamoyl-2-p-nitrobenzylcarbonylamino]ethylthio-7-oxo-1-azabicyclo[3.2.0] hept-2-ene-2-carboxylate (Protected Derivative 13): Rf (silica gel TLC): 0.3 (benzeneacetone, 2:1); IR $v_{\max }(\mathrm{KBr}) \mathrm{cm}^{-1} 1780$ ( $\beta$-lactam), 1720 (ester), 1695 (urethane), 1670 (amide); ${ }^{1} \mathrm{H}$ NMR $\left(\left(\mathrm{CD}_{3}\right)_{2} \mathrm{CO}\right) \delta 1.03\left(3 \mathrm{H}, \mathrm{t}, J=7.5 \mathrm{~Hz}, \mathrm{CH}_{2} \mathrm{CH}_{3}\right), 1.55 \sim 1.95\left(2 \mathrm{H}, \mathrm{m},-\mathrm{CH}_{2} \mathrm{CH}_{3}\right), 2.85 \sim 3.50(5 \mathrm{H}, \mathrm{m}$, $\left.4-\mathrm{H} \times 2,6-\mathrm{H}, \mathrm{l}^{\prime}-\mathrm{H} \times 2\right), 3.98(1 \mathrm{H}, \mathrm{dt}, J=3$ and $9 \mathrm{~Hz}, 5-\mathrm{H}), 4.25 \sim 4.55\left(1 \mathrm{H}, \mathrm{m}, 2^{\prime}-\mathrm{H}\right), 5.24\left(2 \mathrm{H}, \mathrm{s},-\mathrm{OC} \mathrm{H}_{2}-\mathrm{Ar}\right)$, $5.25(1 \mathrm{H}, \mathrm{d}, J=14 \mathrm{~Hz}, \mathrm{C} H \mathrm{H}-\mathrm{Ar}), 5.52(1 \mathrm{H}, \mathrm{d}, J=14 \mathrm{~Hz}, \mathrm{CH} H-\mathrm{Ar}), 6.40 \sim 6.95\left(2 \mathrm{H}, \mathrm{br}, \mathrm{CONH}_{2}\right), 6.95 \sim 7.25$ $(1 \mathrm{H}, \mathrm{br}, \mathrm{NH}), 7.61(2 \mathrm{H}, \mathrm{d}, J=9 \mathrm{~Hz}, \mathrm{Ar}), 7.75(2 \mathrm{H}, \mathrm{d}, J=9 \mathrm{~Hz}, \mathrm{Ar}), 8.20(4 \mathrm{H}, \mathrm{d}, J=9 \mathrm{~Hz}, \mathrm{Ar})$.

3-[(2S)-2-Amino-2-carbamoyl]ethylthio-6-ethyl-7-oxo-1-azabicyclo[3.2.0]hept-2-ene-2-carboxylic Acid (Derivative 13): UV $\lambda_{\max } \mathrm{nm}(\varepsilon) 300(3,500) ;{ }^{1} \mathrm{H} \mathrm{NMR}\left(\mathrm{D}_{2} \mathrm{O}\right) \delta 0.99\left(3 \mathrm{H}, \mathrm{t}, J=7.5 \mathrm{~Hz}, \mathrm{CH}_{2} \mathrm{CH}_{3}\right)$, $1.4 \sim 1.9\left(2 \mathrm{H}, \mathrm{m},-\mathrm{CH}_{2} \mathrm{CH}_{3}\right), 2.6 \sim 3.4\left(5 \mathrm{H}, \mathrm{m}, 4-\mathrm{H} \times 2,6-\mathrm{H}, \mathrm{l}^{\prime}-\mathrm{H} \times 2\right), 3.4 \sim 3.8\left(1 \mathrm{H}, \mathrm{m}, 2^{\prime}-\mathrm{H}\right), 3.97(1 \mathrm{H}$, $\mathrm{dt}, J=3$ and $9 \mathrm{~Hz}, 5-\mathrm{H})$.

p-Nitrobenzyl 6-Ethyl-3-[(2S)-2-p-nitrobenzyloxycarbonylamino-2-N-(pyridin-2-yl)carbamoyl]ethylthio-7-oxo-1-azabicyclo[3.2.0] hept-2-ene-2-carxoxylate (Protected Derivative 14): $\mathrm{Rf}$ (silica gel TLC): 0.41 (benzene-acetone, 5:1); $[\alpha]_{\mathrm{D}}^{23} 25.5^{\circ}$ (c 1.0, THF); UV $\lambda_{\max }^{\mathrm{THF}} \mathrm{nm}(\varepsilon) 269(24,400), 318(12,500)$; IR $v_{\max }\left(\mathrm{CHCl}_{3}\right) \mathrm{cm}^{-1} 1770\left(\beta\right.$-lactam), 1715 (ester), 1695 (urethane, amide); ${ }^{1} \mathrm{H}$ NMR $\left(\mathrm{CDCl}_{3}\right) \delta 1.01(3 \mathrm{H}$, $\left.\mathrm{t}, J=7.5 \mathrm{~Hz}, \mathrm{CH}_{2} \mathrm{CH}_{3}\right), 1.60 \sim 2.00\left(2 \mathrm{H}, \mathrm{m},-\mathrm{CH}_{2} \mathrm{CH}_{3}\right), 2.80 \sim 3.50\left(5 \mathrm{H}, \mathrm{m}, 4-\mathrm{H} \times 2,6-\mathrm{H}, \mathrm{l}^{\prime}-\mathrm{H} \times 2\right), 3.82$ $(1 \mathrm{H}, \mathrm{dt}, J=3$ and $9 \mathrm{~Hz}, 5-\mathrm{H}), 4.50 \sim 4.80\left(1 \mathrm{H}, \mathrm{m}, 2^{\prime}-\mathrm{H}\right), 5.14(1 \mathrm{H}, \mathrm{d}, J=13.5 \mathrm{~Hz},-\mathrm{OCHH}-\mathrm{Ar}), 5.18(2 \mathrm{H}$, $\mathrm{s},-\mathrm{OCH} \mathrm{H}_{2}$-Ar), $5.43(1 \mathrm{H}, \mathrm{d}, J=13.5 \mathrm{~Hz},-\mathrm{OCH} H-\mathrm{Ar}), 6.40(1 \mathrm{H}, \mathrm{d}, J=8 \mathrm{~Hz}, \mathrm{NH}), 7.00(1 \mathrm{H}, \mathrm{dd}, J=5$ and $\left.7.5 \mathrm{~Hz}, 5^{\prime}-\mathrm{H}\right), 7.41(2 \mathrm{H}, \mathrm{d}, J=9 \mathrm{~Hz}, \mathrm{Ar}), 7.53(2 \mathrm{H}, \mathrm{d}, J=9 \mathrm{~Hz}, \mathrm{Ar}), 7.50 \sim 7.8\left(1 \mathrm{H}, \mathrm{m}, 4^{\prime}-\mathrm{H}\right), 8.10(4 \mathrm{H}, \mathrm{d}$, $J=9 \mathrm{~Hz}, \mathrm{Ar}), 7.90 \sim 8.3\left(2 \mathrm{H}, \mathrm{m}, 3^{\prime}-\mathrm{H}, 6^{\prime}-\mathrm{H}\right), 9.47(1 \mathrm{H}, \mathrm{br}, \mathrm{NH})$.

3-[(2S)-2-Amino-2- $N$-(pyridin-2-yl)carbamoyl] ethylthio-6-ethyl-7-oxo-1-azabicyclo[3.2.0]hept2-ene-2-carboxylic Acid (Derivative 14): UV $\lambda_{\max } \mathrm{nm}$ 233, 276, 299.5.

p-Nitrobenzyl 3-[(2S)-2-Dimethylamino-2-p-nitrobenzyloxycarbonyl]ethylthio-7-oxo-1-azabicyclo[3.2.0]hept-2-ene-2-carboxylate (Protected Derivative 15): Rf (silica gel TLC): 0.45 (benzene-acetone, $3: 1) ;[\alpha]_{\mathrm{D}}^{22} 16.7^{\circ}(c 0.7, \mathrm{THF}) ; \mathrm{UV} \lambda_{\max }^{\mathrm{THF}} \mathrm{nm}(\varepsilon) 266(19,600), 321(13,200) ; \mathrm{IR} v_{\max }\left(\mathrm{CHCl}_{3}\right) \mathrm{cm}^{-1} 1770$ ( $\beta$-lactam), 1730 (ester); ${ }^{1} \mathrm{H} \mathrm{NMR}\left(\mathrm{CDCl}_{3}\right) \delta 1.05\left(3 \mathrm{H}, J=7.5 \mathrm{~Hz}, \mathrm{CH}_{2} \mathrm{CH}_{3}\right), 1.5 \sim 2.0\left(2 \mathrm{H}, \mathrm{m},-\mathrm{CH}_{2} \mathrm{CH}_{3}\right)$, $2.34\left(6 \mathrm{H}, \mathrm{s}, \mathrm{N}\left(\mathrm{CH}_{3}\right)_{2}\right), 2.9 \sim 3.3\left(5 \mathrm{H}, \mathrm{m}, 4-\mathrm{H} \times 2,6-\mathrm{H}, 1^{\prime}-\mathrm{H} \times 2\right), 3.45\left(1 \mathrm{H}, \mathrm{dd}, J=7\right.$ and $\left.8 \mathrm{~Hz}, 2^{\prime}-\mathrm{H}\right), 3.95$ $(1 \mathrm{H}, \mathrm{dt}, J=3$ and $9 \mathrm{~Hz}, 5-\mathrm{H}), 5.17(1 \mathrm{H}, \mathrm{d}, J=13 \mathrm{~Hz}, \mathrm{OCHH}-\mathrm{Ar}), 5.25\left(2 \mathrm{H}, \mathrm{s}, \mathrm{OC} H_{2}-\mathrm{Ar}\right), 5.48(1 \mathrm{H}, \mathrm{d}$, $J=13 \mathrm{~Hz}, \mathrm{OCH} H-\mathrm{Ar}), 7.50(2 \mathrm{H}, \mathrm{d}, J=9 \mathrm{~Hz}, \mathrm{Ar}), 7.63(2 \mathrm{H}, \mathrm{d}, J=9 \mathrm{~Hz}, \mathrm{Ar}), 8.18(4 \mathrm{H}, \mathrm{d}, J=9 \mathrm{~Hz}, \mathrm{Ar})$, MS $(m / z) 598\left(\mathrm{M}^{+}\right), 418\left(\mathrm{M}^{+}-\mathrm{COOpNB}\right)$.

Sodium 3-[(2S)-2-Carboxy-2-dimethylamino]ethylthio-6-ethyl-7-oxo-1-azabicyclo[3.2.0]hept-2-ene2-carboxylate (Derivative 15): UV $\lambda_{\max } \mathrm{nm}(\varepsilon) 299(8,000)$ (in $0.01 \mathrm{M}$ phosphate buffer, $\mathrm{pH} 7.5$ ); ${ }^{1} \mathrm{H}$ NMR $\left(\mathrm{D}_{2} \mathrm{O}\right) \delta 0.98\left(3 \mathrm{H}, \mathrm{t}, J=7.5 \mathrm{~Hz}, \mathrm{CH}_{2} \mathrm{CH}_{3}\right), 1.55 \sim 1.95\left(2 \mathrm{H}, \mathrm{m},-\mathrm{CH}_{2} \mathrm{CH}_{3}\right), 2.84\left(6 \mathrm{H}, \mathrm{s}, \mathrm{N}\left(\mathrm{CH}_{3}\right)_{2}\right)$, 
$3.05 \sim 3.4(3 \mathrm{H}, \mathrm{m}, 4-\mathrm{H} \times 2,6-\mathrm{H}), 3.32\left(2 \mathrm{H}, \mathrm{d}, J=5.5 \mathrm{~Hz}, 1^{\prime}-\mathrm{H} \times 2\right), 4.02(1 \mathrm{H}, \mathrm{dt}, J=3$ and $9 \mathrm{~Hz}, 5-\mathrm{H}), 4.18$ $\left(1 \mathrm{H}, \mathrm{t}, J=5.5 \mathrm{~Hz}, 2^{\prime}-\mathrm{H}\right)$.

$p$-Nitrobenzyl 3-[(2S)-2-Acetylamino-2-p-nitrobenzyloxycarbonyl]ethylthio-6-ethyl-7-oxo-1-azabicyclo[3.2.0]hept-2-ene-2-carboxylate (Protected Derivative 16): Rf (silica gel TLC): 0.60 (benzeneacetone, $1: 1) ;[\alpha]_{\mathrm{D}}^{24} 37.0^{\circ}\left(c 1.0, \mathrm{CH}_{2} \mathrm{Cl}_{2}\right)$; UV $\lambda_{\max }^{\mathrm{CH}_{2} \mathrm{Cl}_{2}} \mathrm{~nm}(\varepsilon) 269(24,500), 317(14,700) ; \mathrm{IR} v_{\max }\left(\mathrm{CH}_{2} \mathrm{Cl}_{2}\right)$ $\mathrm{cm}^{-1} 1775$ ( $\beta$-lactam), 1748 and 1700 (ester), 1680 (amide); ${ }^{1} \mathrm{H}$ NMR $\left(\mathrm{CDCl}_{3}\right) \delta 1.03(3 \mathrm{H}, \mathrm{t}, J=7 \mathrm{~Hz}$, $\left.\mathrm{CH}_{2} \mathrm{CH}_{3}\right), 1.67 \sim 2.00\left(2 \mathrm{H}, \mathrm{m},-\mathrm{CH}_{2} \mathrm{CH}_{3}\right), 2.00\left(3 \mathrm{H}, \mathrm{s}, \mathrm{COCH}_{3}\right), 2.80 \sim 3.53\left(5 \mathrm{H}, \mathrm{m}, 4-\mathrm{H} \times 2,6-\mathrm{H}, 1^{\prime}-\mathrm{H} \times 2\right)$, $3.90(1 \mathrm{H}, \mathrm{dt}, J=3$ and $9 \mathrm{~Hz}, 5-\mathrm{H}), 4.70 \sim 4.85\left(1 \mathrm{H}, \mathrm{m}, 2^{\prime}-\mathrm{H}\right), 5.15(1 \mathrm{H}, \mathrm{d}, J=14 \mathrm{~Hz}, \mathrm{CHH}-\mathrm{Ar}), 5.23(2 \mathrm{H}$, s, $\mathrm{CH}_{2}$-Ar), $5.47(1 \mathrm{H}, \mathrm{d}, J=14 \mathrm{~Hz}, \mathrm{CH} H-\mathrm{Ar}), 6.25(1 \mathrm{H}, \mathrm{d}, J=8 \mathrm{~Hz}, \mathrm{NH}), 7.47(2 \mathrm{H}, \mathrm{d}, J=9 \mathrm{~Hz}, \mathrm{Ar}), 7.60$ $(2 \mathrm{H}, \mathrm{d}, J=9 \mathrm{~Hz}, \mathrm{Ar}), 8.17(4 \mathrm{H}, \mathrm{d}, J=9 \mathrm{~Hz}, \mathrm{Ar})$.

Disodium 3-[(2S)-2-Acetylamino-2-carboxy]ethylthio-6-ethyl-7-oxo-1-azabicyclo[3.2.0]hept-2-ene-2carboxylate (Derivative 16): UV $\lambda_{\max } \mathrm{nm}(\varepsilon) 301.5(9,200)$ (in $0.01 \mathrm{M}$ phosphate buffer, $\mathrm{pH} 7.5$ ); ${ }^{1} \mathrm{H}$ NMR $\left(\mathrm{D}_{2} \mathrm{O}\right) \delta 0.98\left(3 \mathrm{H}, \mathrm{t}, J=7.5 \mathrm{~Hz}, \mathrm{CH}_{2} \mathrm{CH}_{3}\right), 1.6 \sim 1.9\left(2 \mathrm{H}, \mathrm{m},-\mathrm{CH}_{2} \mathrm{CH}_{3}\right), 2.02\left(3 \mathrm{H}, \mathrm{s}, \mathrm{COCH}_{3}\right)$, $2.8 \sim 3.5\left(5 \mathrm{H}, \mathrm{m}, 4-\mathrm{H} \times 2,6-\mathrm{H}, 1^{\prime}-\mathrm{H}\right), 3.98(1 \mathrm{H}, \mathrm{dt}, J=3$ and $9 \mathrm{~Hz}, 5-\mathrm{H}), 4.37\left(1 \mathrm{H}, \mathrm{dd}, J=5\right.$ and $\left.7 \mathrm{~Hz}, 2^{\prime}-\mathrm{H}\right)$.

$p$-Nitrobenzyl 6-Ethyl-3-[(2S)-2-p-nitrobenzyloxycarbonyl-2-(pyridin-4-yl)carbonylamino]ethylthio7-oxo-1-azabicyclo[3.2.0] hept-2-ene-2-carboxylate (Protected Derivative 17): Rf (silica gel TLC): 0.6 (benzene-acetone, $1: 1) ;[\alpha]_{\mathrm{D}}^{22} 25.9^{\circ}$ (c 1.0, THF); UV $\lambda_{\max }^{\mathrm{THF}} \mathrm{nm}(\varepsilon) 265.5(21,200), 318.5(11,700)$; IR $v_{\max }\left(\mathrm{CHCl}_{3}\right) \mathrm{cm}^{-1} 1775$ ( $\beta$-lactam), 1750 (ester), 1670 (amide); ${ }^{1} \mathrm{H} \mathrm{NMR}\left(\mathrm{CDCl}_{3}\right) \delta 1.02(3 \mathrm{H}, \mathrm{t}, J=7.5 \mathrm{~Hz}$, $\left.\mathrm{CH}_{2} \mathrm{CH}_{3}\right), 1.6 \sim 1.9\left(2 \mathrm{H}, \mathrm{m},-\mathrm{CH}_{2} \mathrm{CH}_{3}\right), 2.8 \sim 3.3(3 \mathrm{H}, \mathrm{m}, 4-\mathrm{H} \times 2,6-\mathrm{H}), 3.30 \sim 3.60\left(2 \mathrm{H}, \mathrm{m}, \mathrm{l}^{\prime}-\mathrm{H} \times 2\right)$, $3.82(1 \mathrm{H}, \mathrm{dt}, J=3$ and $9 \mathrm{~Hz}, 5-\mathrm{H}), 4.90 \sim 5.20\left(1 \mathrm{H}, \mathrm{m}, 2^{\prime}-\mathrm{H}\right), 5.15(1 \mathrm{H}, \mathrm{d}, J=14 \mathrm{~Hz},-\mathrm{OCHH}-\mathrm{Ar}), 5.30$ $\left(2 \mathrm{H}, \mathrm{s},-\mathrm{OCH} \mathrm{H}_{2}-\mathrm{Ar}\right), 5.45(1 \mathrm{H}, \mathrm{d}, J=14 \mathrm{~Hz},-\mathrm{OCH}-\mathrm{Ar}), 7.2 \sim 7.4(1 \mathrm{H}, \mathrm{br}, \mathrm{NH}), 7.40 \sim 7.70(6 \mathrm{H}, \mathrm{m}, \mathrm{Ar})$, $8.17(4 \mathrm{H}, \mathrm{d}, J=9 \mathrm{~Hz}, \mathrm{Ar}), 8.60 \sim 8.80(2 \mathrm{H}, \mathrm{m}, \mathrm{Ar})$.

Disodium 3-[(2S)-2-Carboxy-2-(pyridin-4-yl)carbonylamino]ethyl-6-ethyl-7-oxo-1-azabicyclo[3.2.0]hept-2-ene-2-carboxylate (Derivative 17): UV $\lambda_{\max } \mathrm{nm}(\varepsilon) 302(8,200)$ (in $0.01 \mathrm{M}$ phosphate buffer, $\mathrm{pH}$ 7.5); ${ }^{1} \mathrm{H}$ NMR $\left(\mathrm{D}_{2} \mathrm{O}\right) \delta 0.90\left(3 \mathrm{H}, \mathrm{t}, J=7.5 \mathrm{~Hz}, \mathrm{CH}_{2} \mathrm{CH}_{3}\right), 1.50 \sim 1.90\left(2 \mathrm{H}, \mathrm{m},-\mathrm{CH}_{2} \mathrm{CH}_{3}\right), 2.80 \sim 3.20$ $(3 \mathrm{H}, \mathrm{m}, 4-\mathrm{H} \times 2,6-\mathrm{H}), 3.20 \sim 3.45\left(2 \mathrm{H}, \mathrm{m}, \mathrm{I}^{\prime}-\mathrm{H} \times 2\right), 3.77(1 \mathrm{H}, \mathrm{dt}, J=3$ and $9 \mathrm{~Hz}, 5-\mathrm{H}), 4.63(1 \mathrm{H}, \mathrm{dd}, J=4.5$ and $\left.7.5 \mathrm{~Hz}, 2^{\prime}-\mathrm{H}\right), 7.72(2 \mathrm{H}, \mathrm{dd}, J=4.5$ and $2 \mathrm{~Hz}$, pyridine $-\beta \times 2), 8.65(2 \mathrm{H}, \mathrm{dd}, J=4.5$ and $2 \mathrm{~Hz}$, pyridine- $\alpha \times 2$ ).

p-Nitrobenzyl 6-[(2S)-2-Amino-3-((5R,6R)-6-ethyl-2-p-nitrobenzyloxycarbonyl-7-oxo-1-azabicyclo[3.2.0] hept-2-ene-3-yl)thio]propionylaminopenicillanate (Protected Derivative 18): Rf (silica gel TLC): 0.37 (benzene-acetone, 4:1); $[\alpha]_{\mathrm{D}}^{24} 110.6^{\circ}$ (c 1.0, THF); UV $\lambda_{\max }^{\mathrm{THF}} \mathrm{nm}(\varepsilon) 267 \quad(27,800), 320(11,100)$; IR $v_{\max }\left(\mathrm{CHCl}_{3}\right) \mathrm{cm}^{-1} 1775$ ( $\beta$-lactam), 1750 (ester), 1720 (urethane), 1680 (amide); ${ }^{1} \mathrm{H}$ NMR $\left(\mathrm{CDCl}_{3}\right) \delta$ $1.05\left(3 \mathrm{H}, \mathrm{t}, J=7.5 \mathrm{~Hz}, \mathrm{CH}_{2} \mathrm{CH}_{3}\right), 1.38\left(3 \mathrm{H}, \mathrm{s}, \mathrm{CH}_{3} \mathrm{CCH}_{3}\right), 1.55\left(3 \mathrm{H}, \mathrm{s}, \mathrm{CH}_{3} \mathrm{CCH}_{3}\right), 1.60 \sim 2.10(2 \mathrm{H}, \mathrm{m}$, $\left.\mathrm{CH}_{2} \mathrm{CH}_{3}\right), 2.80 \sim 3.60\left(5 \mathrm{H}, \mathrm{m}, 4-\mathrm{H} \times 2,6-\mathrm{H}, \mathrm{SCH}_{2}-\right), 3.97(1 \mathrm{H}, \mathrm{dt}, J=3$ and $9 \mathrm{~Hz}, 5-\mathrm{H}), 4.20 \sim 4.50(1 \mathrm{H}$, $\left.\mathrm{m},-\mathrm{SCH}_{2} \mathrm{CHCO}\right), 4.44\left(1 \mathrm{H}, \mathrm{s}, 3^{\prime}-\mathrm{H}\right), 5.18(1 \mathrm{H}, \mathrm{d}, J=14 \mathrm{~Hz}, \mathrm{OCHH}-\mathrm{Ar}), 5.20\left(2 \mathrm{H}, \mathrm{s}, \mathrm{OCH}_{2}-\mathrm{Ar}\right), 5.27$ $\left(2 \mathrm{H}, \mathrm{s}, \mathrm{OCH}_{2}-\mathrm{Ar}\right), 5.48(1 \mathrm{H}, \mathrm{d}, J=14 \mathrm{~Hz}, \mathrm{OCH} H-\mathrm{Ar}), 5.40 \sim 5.70\left(2 \mathrm{H}, \mathrm{m}, 5^{\prime}-\mathrm{H}, 6^{\prime}-\mathrm{H}\right), 5.88(1 \mathrm{H}, \mathrm{d}, J=8 \mathrm{~Hz}$, $\mathrm{NH}), 7.00 \sim 7.4(1 \mathrm{H}, \mathrm{m}, \mathrm{NH}), 7.48(2 \mathrm{H}, \mathrm{d}, J=9 \mathrm{~Hz}, \mathrm{Ar}), 7.53(2 \mathrm{H}, \mathrm{d}, J=9 \mathrm{~Hz}, \mathrm{Ar}), 7.63(2 \mathrm{H}, \mathrm{d}, J=9 \mathrm{~Hz}$, Ar), $8.20(4 \mathrm{H}, \mathrm{d}, J=9 \mathrm{~Hz}, \mathrm{Ar}), 8.23(2 \mathrm{H}, \mathrm{d}, J=9 \mathrm{~Hz}, \mathrm{Ar})$.

Sodium 6-[(2S)-2-Amino-3-((5R,6R)-2-carboxy-6-ethyl-7-oxo-1-azabicyclo[3.2.0]hept-2-ene-3-yl)thio]propionylaminopenicillanate (Derivative 18): UV $\lambda_{\max } \mathrm{nm}(\varepsilon) 300(8,100)$ (in $0.01 \mathrm{~m}$ phosphate buffer, pH 6.8); ${ }^{1} \mathrm{H}$ NMR ( $\mathrm{D}_{2} \mathrm{O}$, external standard TMS) $\delta 1.44\left(3 \mathrm{H}, \mathrm{t}, J=7.5 \mathrm{~Hz}, \mathrm{CH}_{2} \mathrm{CH}_{3}\right), 1.96(3 \mathrm{H}$, s, $\left.\mathrm{CH}_{3} \mathrm{CCH}_{3}\right), 2.07\left(3 \mathrm{H}, \mathrm{s}, \mathrm{CH}_{3} \mathrm{CCH}_{3}\right), 1.80 \sim 2.40\left(2 \mathrm{H}, \mathrm{m},-\mathrm{CH}_{2} \mathrm{CH}_{3}\right), 3.40 \sim 3.90(5 \mathrm{H}, \mathrm{m}, 4-\mathrm{H} \times 2,6-\mathrm{H}$, $\left.-\mathrm{SCH} \mathrm{H}_{2} \mathrm{CH}\right), 4.10 \sim 4.40\left(1 \mathrm{H}, \mathrm{m}, \mathrm{SCH}_{2} \mathrm{CH}-\right), 4.44(1 \mathrm{H}, \mathrm{dt}, J=3$ and $9 \mathrm{~Hz}, 5-\mathrm{H}), 4.66\left(1 \mathrm{H}, \mathrm{s}, 3^{\prime}-\mathrm{H}\right)$, $5.80 \sim 6.10\left(2 \mathrm{H}, \mathrm{m}, 5^{\prime}-\mathrm{H}, 6^{\prime}-\mathrm{H}\right)$.

$p$-Nitrobenzyl 6-Ethyl-3-[(2S)-1,1-dimethy]-2-p-nitrobenzyloxycarbonylamino-2-p-nitrobenzyloxycarbonyl]ethylthio-7-oxo-1-azabicyclo[3.2.0]hept-2-ene-2-carboxylate (Protected Derivative 19): Rf (silica gel TLC): 0.53 (benzene-acetone, $5: 1) ;[\alpha]_{\mathrm{D}}^{23} 33.6^{\circ}$ (c 1.0, THF); UV $\lambda_{\max }^{\mathrm{THF}} \mathrm{nm}(\varepsilon) 264(24,700), 320(9,000)$; IR $v_{\max }\left(\mathrm{CHCl}_{3}\right) \mathrm{cm}^{-1} 1772\left(\beta\right.$-lactam), 1720 (ester, urethane); ${ }^{1} \mathrm{H}$ NMR $\left(\mathrm{CDCl}_{3}\right) \delta 1.06(3 \mathrm{H}, \mathrm{t}, J=7.5 \mathrm{~Hz}$, $\left.\mathrm{CH}_{2} \mathrm{CH}_{3}\right), 1.47\left(3 \mathrm{H}, \mathrm{s}, \mathrm{CH}_{3} \mathrm{CCH}_{3}\right), 1.52\left(3 \mathrm{H}, \mathrm{s}, \mathrm{CH}_{3} \mathrm{CCH}_{3}\right), 1.60 \sim 2.10\left(2 \mathrm{H}, \mathrm{m},-\mathrm{CH}_{2} \mathrm{CH}_{3}\right), 2.90 \sim 3.55$ $(3 \mathrm{H}, \mathrm{m}, 4-\mathrm{H} \times 2,6-\mathrm{H}), 3.91(1 \mathrm{H}, \mathrm{dt}, J=3$ and $9 \mathrm{~Hz}, 5-\mathrm{H}), 4.62\left(1 \mathrm{H}, \mathrm{d}, J=9 \mathrm{~Hz}, 2^{\prime}-\mathrm{H}\right), 5.17(1 \mathrm{H}, \mathrm{d}$, $J=13.5 \mathrm{~Hz}, \mathrm{CHH}-\mathrm{Ar}), 5.18\left(2 \mathrm{H}, \mathrm{s}, \mathrm{CH}_{2}-\mathrm{Ar}\right), 5.23\left(2 \mathrm{H}, \mathrm{s}, \mathrm{CH}_{2}-\mathrm{Ar}\right), 5.46(1 \mathrm{H}, \mathrm{d}, J=13.5 \mathrm{~Hz}, \mathrm{CH} H-\mathrm{Ar})$, $5.95(1 \mathrm{H}, \mathrm{d}, J=9 \mathrm{~Hz}, \mathrm{NH}), 7.48(2 \mathrm{H}, \mathrm{d}, J=9 \mathrm{~Hz}, \mathrm{Ar}), 7.49(2 \mathrm{H}, \mathrm{d}, J=9 \mathrm{~Hz}, \mathrm{Ar}), 7.62(2 \mathrm{H}, \mathrm{d}, J=9 \mathrm{~Hz}$, Ar), $8.17(2 \mathrm{H}, \mathrm{d}, J=9 \mathrm{~Hz}, \mathrm{Ar})$. 
Sodium 3-[(2S)-2-Amino-2-carboxy-1,1-dimethyl]ethylthio-6-ethyl-7-oxo-1-azabicyclo[3.2.0]hept-2ene-2-carboxylate (Derivative 19): UV $\lambda_{\max } \mathrm{nm}(\varepsilon) 283(5,600)$ (in $0.01 \mathrm{M}$ phosphate buffer, $\mathrm{pH} 7.2$ ); ${ }^{1} \mathrm{H}$ NMR $\left(\mathrm{D}_{2} \mathrm{O}\right.$, external standard TMS) $\delta 1.44\left(3 \mathrm{H}, \mathrm{t}, J=7.5 \mathrm{~Hz}, \mathrm{CH}_{2} \mathrm{CH}_{3}\right), 1.78\left(3 \mathrm{H}, \mathrm{s}, \mathrm{CH}_{3} \mathrm{CCH}_{3}\right)$, $2.12\left(3 \mathrm{H}, \mathrm{s}, \mathrm{CH}_{3} \mathrm{CCH}_{3}\right), 1.90 \sim 2.4\left(2 \mathrm{H}, \mathrm{m},-\mathrm{CH}_{2} \mathrm{CH}_{3}\right), 3.43(1 \mathrm{H}, \mathrm{dd}, J=10$ and $18 \mathrm{~Hz}, 4-\mathrm{Ha}), 3.70(1 \mathrm{H}$, $\mathrm{dd}, J=8$ and $18 \mathrm{~Hz}, 4-\mathrm{Hb}), 3.85(1 \mathrm{H}, \mathrm{dt}, J=3$ and $7 \mathrm{~Hz}, 6-\mathrm{H}), 4.04\left(1 \mathrm{H}, \mathrm{s}, 2^{\prime}-\mathrm{H}\right), 4.54(1 \mathrm{H}, \mathrm{ddd}, J=3$, 8 and $10 \mathrm{~Hz}, 5-\mathrm{H})$.

$p$-Nitrobenzyl 6-Ethyl-3-furfurylthio-7-oxo-1-azabicyclo[3.2.0]hept-2-ene-2-carboxylate (Protected Derivative 20): $[\alpha]_{\mathrm{D}}^{22} 18.6^{\circ}\left(c 1.0\right.$, THF); UV $\lambda_{\max }^{\mathrm{THF}} \mathrm{nm}(\varepsilon) 268(14,500), 320(14,800)$; IR $v_{\max }\left(\mathrm{CHCl}_{3}\right)$ $\mathrm{cm}^{-1} 1775$ ( $\beta$-lactam), 1700 (ester); ${ }^{1} \mathrm{H}$ NMR $\left(\mathrm{CDCl}_{3}\right) \delta 1.04\left(3 \mathrm{H}, \mathrm{t}, J=8.0 \mathrm{~Hz}, \mathrm{CH}_{2} \mathrm{CH}_{3}\right), 1.82(2 \mathrm{H}, \mathrm{m}$, $\left.-\mathrm{CH}_{2} \mathrm{CH}_{3}\right), 3.06(1 \mathrm{H}, \mathrm{dd}, J=18$ and $9 \mathrm{~Hz}, 4-\mathrm{Ha}), 3.10(1 \mathrm{H}, \mathrm{m}, 6-\mathrm{H}), 3.38(1 \mathrm{H}, \mathrm{dd}, J=18$ and $9 \mathrm{~Hz}, 4-\mathrm{Hb})$, $3.96(1 \mathrm{H}, \mathrm{dt}, J=3$ and $9 \mathrm{~Hz}, 5-\mathrm{H}), 4.02\left(2 \mathrm{H}, \mathrm{s}, \mathrm{CH}_{2}\right.$-fur $), 5.21(1 \mathrm{H}, \mathrm{d}, J=14 \mathrm{~Hz}, \mathrm{CHH}-\mathrm{Ar}), 5.50(1 \mathrm{H}, \mathrm{d}$, $J=14 \mathrm{~Hz}, \mathrm{CH} H$-Ar $), 6.20 \sim 6.40\left(2 \mathrm{H}, \mathrm{m}, 3^{\prime}-\mathrm{H}, 4^{\prime}-\mathrm{H}\right), 7.32\left(1 \mathrm{H}, \mathrm{m}, 5^{\prime}-\mathrm{H}\right), 7.63(2 \mathrm{H}, \mathrm{d}, J=9 \mathrm{~Hz}, \mathrm{Ar}), 8.18$ $(2 \mathrm{H}, \mathrm{d}, J=9 \mathrm{~Hz}, \mathrm{Ar}) \mathrm{MS}(m / z) 428\left(\mathrm{M}^{+}\right)$.

Sodium 6-Ethyl-3-furfurylthio-7-oxo-1-azabicyclo[3.2.0]hept-2-ene-2-carboxylate (Derivative 20): UV $\lambda_{\max } \mathrm{nm}(\varepsilon) 301(10,900) ;{ }^{1} \mathrm{H}$ NMR $\left(\mathrm{D}_{2} \mathrm{O}\right) \delta 1.00\left(3 \mathrm{H}, \mathrm{t}, J=7.5 \mathrm{~Hz}, \mathrm{CH}_{2} \mathrm{CH}_{3}\right), 1.80(2 \mathrm{H}, \mathrm{m}$, $\left.-\mathrm{CH}_{2} \mathrm{CH}_{3}\right), 3.04(1 \mathrm{H}, \mathrm{dd}, J=9$ and $18 \mathrm{~Hz}, 4-\mathrm{Ha}), 3.23(1 \mathrm{H}, \mathrm{m}, 6-\mathrm{H}), 3.32(1 \mathrm{H}, \mathrm{dd}, J=9$ and $18 \mathrm{~Hz} .4-\mathrm{Hb})$, $3.99(1 \mathrm{H}, \mathrm{dt}, J=3$ and $9 \mathrm{~Hz}, 5-\mathrm{H}), 4.08\left(2 \mathrm{H}, \mathrm{s}, \mathrm{CH}_{2}\right.$-fur $), 6.40\left(2 \mathrm{H}, \mathrm{m}, 3^{\prime}-\mathrm{H}, 4^{\prime}-\mathrm{H}\right), 7.49(1 \mathrm{H}, \mathrm{d}, J=1.5 \mathrm{~Hz}$, $\left.5^{\prime}-\mathrm{H}\right)$.

p-Nitrobenzyl 6-Ethyl-3-[N-(2-methyl-1-p-nitrobenzyloxycarbonyl-1-propenyl)carbamoyl]methylthio-7-oxo-1-azabicyclo[3.2.0]hept-2-ene-2-carboxylate (Protected Derivative 23): Rf (silica gel TLC): 0.27 (benzene-acetone, 5:1); $[\alpha]_{\mathrm{D}}^{23} 16.7^{\circ}$ (c 1.0, THF), UV $\lambda_{\max }^{\mathrm{THF}} \mathrm{nm}(\varepsilon) 243(16,300), 265(22,500), 318$ $(12,900)$; IR $v_{\max }\left(\mathrm{CHCl}_{3}\right) \mathrm{cm}^{-1} 1775$ ( $\beta$-lactam), 1720, 1700 (ester), 1685 (amide); ${ }^{1} \mathrm{H}$ NMR $\left(\mathrm{CDCl}_{3}\right) \delta$ $1.02\left(3 \mathrm{H}, \mathrm{t}, J=7.5 \mathrm{~Hz}, \mathrm{CH}_{2} \mathrm{CH}_{3}\right), 1.6 \sim 2.0\left(2 \mathrm{H}, \mathrm{m},-\mathrm{CH}_{2} \mathrm{CH}_{3}\right), 1.85\left(3 \mathrm{H}, \mathrm{s}, \mathrm{CH}_{3}{ }_{\mathrm{CCH}}\right), 2.17(3 \mathrm{H}, \mathrm{m}$, $\left.\mathrm{CH}_{3} \stackrel{\| C}{\mathrm{CC}} \mathrm{H}_{3}\right), 2.9 \sim 3.3(3 \mathrm{H}, \mathrm{m}, 4-\mathrm{H} \times 2,6-\mathrm{H}), 3.55\left(2 \mathrm{H}, \mathrm{s},-\mathrm{SCH} \mathrm{H}_{2} \mathrm{CO}\right), 3.89(1 \mathrm{H}, \mathrm{dt}, J=3$ and $9 \mathrm{~Hz}, 5-\mathrm{H})$, $5.22(1 \mathrm{H}, \mathrm{d}, J=14 \mathrm{~Hz},-\mathrm{CHH}-\mathrm{Ar}), 5.27\left(2 \mathrm{H}, \mathrm{s}, \mathrm{CH}_{2}-\mathrm{Ar}\right), 5.50(1 \mathrm{H}, \mathrm{d}, J=14 \mathrm{~Hz},-\mathrm{CH} H-\mathrm{Ar}), 7.52(2 \mathrm{H}, \mathrm{d}$, $J=9 \mathrm{~Hz}, \mathrm{Ar}), 7.4 \sim 7.7(1 \mathrm{H}, \mathrm{m},-\mathrm{NH}-), 8.18(4 \mathrm{H}, \mathrm{d}, J=9 \mathrm{~Hz}, \mathrm{Ar}), \mathrm{MS}(m / z) 568\left(\mathrm{M}^{+}-\mathrm{EtCH}=\mathrm{C}=\mathrm{O}\right)$.

Disodium 6-Ethyl-3-[ $N$-(1-carboxy-2-methyl-1-propenyl)carbamoyl]methylthio-7-oxo-1-azabicyclo[3.2.0]hept-2-ene-2-carboxylate (Derivative 23): UV $\lambda_{\max } \mathrm{nm}(\varepsilon) 299(8,800)$ (in $0.01 \mathrm{~m}$ phosphate buffer, pH 7.5), ${ }^{1} \mathrm{H}$ NMR $\left(\mathrm{D}_{2} \mathrm{O}\right.$, external standard TMS) $\delta 1.43\left(3 \mathrm{H}, \mathrm{t}, J=7.5 \mathrm{~Hz},-\mathrm{CH}_{2} \mathrm{CH}_{3}\right), 2.0 \sim 2.4$ $\left(2 \mathrm{H}, \mathrm{m},-\mathrm{CH}_{2} \mathrm{CH}_{3}\right), 2.17\left(3 \mathrm{H}, \mathrm{s}, \mathrm{CH}_{3}{ }_{3} \mathrm{CCH}_{3}\right), 2.42\left(3 \mathrm{H}, \mathrm{s}, \mathrm{CH}_{3} \stackrel{\text { II }}{\mathrm{CCH}} \mathrm{CH}_{3}\right), 3.3 \sim 3.9(3 \mathrm{H}, \mathrm{m}, 4-\mathrm{H} \times 2,6-\mathrm{H}), 4.12$ $\left(2 \mathrm{H}, \mathrm{s},-\mathrm{SCH}_{2} \mathrm{CO}\right), 4.45(1 \mathrm{H}, \mathrm{dt}, J=3$ and $9 \mathrm{~Hz}, 5-\mathrm{H})$.

$p$-Nitrobenzyl 3-[N-(2-Aminopyridin-6-yl)carbamoyl]methylthio-6-ethyl-7-oxo-1-azabicyclo[3.2.0]hept-2-ene-2-carboxylate (Protected Derivative 24): Rf (silica gel TLC): 0.37 (benzene-acetone, $2: 1) ;[\alpha]_{\mathrm{D}}^{24}-12.3^{\circ}(c 1.0, \mathrm{THF})$; UV $\lambda_{\max }^{\mathrm{THF}} \mathrm{nm}(\varepsilon) 255$ (sh, 11,600), $259(12,700), 314(18,500)$; IR $v_{\max }$ $\left(\mathrm{CHCl}_{3}\right) \mathrm{cm}^{-1} 1778\left(\beta\right.$-lactam), 1710 (ester), 1690 (amide); ${ }^{1} \mathrm{H} \mathrm{NMR}\left(\mathrm{CDCl}_{3}\right) \delta 1.02(3 \mathrm{H}, \mathrm{t}, J=7.5 \mathrm{~Hz}$, $\left.\mathrm{CH}_{2} \mathrm{CH}_{3}\right), 1.6 \sim 2.0\left(2 \mathrm{H}, \mathrm{m},-\mathrm{CH}_{2} \mathrm{CH}_{3}\right), 2.8 \sim 3.45(3 \mathrm{H}, \mathrm{m}, 4-\mathrm{H} \times 2,6-\mathrm{H}), 3.60\left(2 \mathrm{H}, \mathrm{s}, \mathrm{SCH}{ }_{2} \mathrm{CO}\right), 3.93$ $(1 \mathrm{H}, \mathrm{dt}, J=3$ and $9 \mathrm{~Hz}, 5-\mathrm{H}), 4.2 \sim 4.65\left(2 \mathrm{H}, \mathrm{br}, \mathrm{NH}_{2}\right), 5.21(1 \mathrm{H}, \mathrm{d}, J=14 \mathrm{~Hz}, \mathrm{CHH}-\mathrm{Ar}), 5.47(1 \mathrm{H}, \mathrm{d}$, $J=14 \mathrm{~Hz}, \mathrm{CH} H-\mathrm{Ar}), 6.22\left(1 \mathrm{H}, \mathrm{dd}, J=3\right.$ and $\left.6 \mathrm{~Hz}, 4^{\prime}-\mathrm{H}\right), 7.30 \sim 7.45\left(2 \mathrm{H}, \mathrm{m}, 3^{\prime}-\mathrm{H}, 5^{\prime}-\mathrm{H}\right), 7.62(2 \mathrm{H}, \mathrm{d}$, $J=9 \mathrm{~Hz}, \mathrm{Ar}), 8.16(2 \mathrm{H}, \mathrm{d}, J=9 \mathrm{~Hz}, \mathrm{Ar}), 8.70(1 \mathrm{H}, \mathrm{s}, \mathrm{NH}), \mathrm{MS}(\mathrm{m} / z) 497\left(\mathrm{M}^{+}\right)$.

3-[N-(2-Aminopyridin-6-yl)carbamoyl] methylthio-6-ethyl-7-oxo-1-azabicyclo[3.2.0]hept-2-ene-2carboxylic Acid (Derivative 24): ${ }^{1} \mathrm{H}$ NMR $\left(\mathrm{D}_{2} \mathrm{O}\right.$, external standard TMS) $\delta 1.38(3 \mathrm{H}, \mathrm{t}, J=7.5 \mathrm{~Hz}$, $\left.\mathrm{CH}_{2} \mathrm{CH}_{3}\right), 2.19\left(2 \mathrm{H}, \mathrm{m}, \mathrm{CH}_{2} \mathrm{CH}_{3}\right), 3.3 \sim 3.8(3 \mathrm{H}, \mathrm{m}, 4-\mathrm{H} \times 2,6-\mathrm{H}), 4.16\left(2 \mathrm{H}, \mathrm{s}, \mathrm{SCH}{ }_{2} \mathrm{CO}\right), 4.39(1 \mathrm{H}, \mathrm{dt}$, $J=3$ and $9 \mathrm{~Hz}), 6.90\left(1 \mathrm{H}, \mathrm{d}, J=8 \mathrm{~Hz}, 3^{\prime}-\mathrm{H}\right), 7.40\left(1 \mathrm{H}, \mathrm{d}, J=7.5 \mathrm{~Hz}, 5^{\prime}-\mathrm{H}\right), 7.98(1 \mathrm{H}$, dd, $J=7.5 \mathrm{and} 8 \mathrm{~Hz}$, $\left.4^{\prime}-\mathrm{H}\right)$.

p-Nitrobenzyl 6-[(5R,6R)-6-Ethyl-2-nitrobenzyloxycarbonyl-7-oxo-1-azabicyclo[3.2.0]hept-2-ene-3yl] thioacetylaminopenicillanate (Protected Derivative 25; A Typical Example of Derivation Through Route B): PS-5 $p$-nitrobenzyl ester $S$-oxide $(20 \mathrm{mg})$ was dissolved in $10 \mathrm{ml}$ of dry DMF and cooled to $-35^{\circ} \mathrm{C}$. To the solution, $0.36 \mathrm{ml}$ of sodium bisulfide hydrate in DMF $\left(10 \mathrm{mg} / \mathrm{ml}\right.$ of $\left.\mathrm{NaSH} \mathrm{H}_{2} \mathrm{O}\right)$ was slowly added under agitation and stirred for 10 minutes at $-35^{\circ} \mathrm{C}$. Then $25 \mu \mathrm{l}$ of triethylamine was added to the solution and warmed to room temperature. $p$-Nitrobenzyl 6-chloroacetylaminopenicillanate $(22.8 \mathrm{mg})$ in $1.5 \mathrm{ml}$ of DMF was gradually added into the said solution and allowed to react for 2 hours under agitation. The reaction mixture was poured in $150 \mathrm{ml}$ of benzene and then washed with $0.1 \mathrm{M}$ phosphate 
buffer, $\mathrm{pH} 6.8(60 \mathrm{ml} \times 3)$. The benzene phase was dried over anhydrous sodium sulfate and condensed to $1.5 \mathrm{ml}$ in vacuo. The condensate was charged on a silica gel column $(20 \mathrm{~g})$. The elution was performed with a solvent mixture of benzene and acetone $(10: 1)$. By silica gel TLC monitoring with a solvent system of benzene and acetone $(5: 1)$, eluate fractions were collected which contained a UV-absorbing material at Rf 0.25 . The evaporation of the solvent in vacuo yielded $166 \mathrm{mg}$ of the title compound (yield $50.4 \%$ ). $[\alpha]_{D}^{25}$ $118.8^{\circ}\left(c 1.0\right.$, THF); UV $\lambda_{\max }^{\mathrm{THF}} \mathrm{nm}(\varepsilon) 267.5(21,000), 317(11,800)$; IR $v_{\max }\left(\mathrm{CHCl}_{3}\right) \mathrm{cm}^{-1} 1780$ ( $\beta$-lactam), 1750 (ester), 1687 (amide); ${ }^{1} \mathrm{H}$ NMR $\left(\mathrm{CDCl}_{3}\right) \delta 1.04\left(3 \mathrm{H}, \mathrm{t}, J=7 \mathrm{~Hz}, \mathrm{CH}_{2} \mathrm{CH}_{3}\right), 1.39,1.48(3 \mathrm{H}$, each, s, $\left.2^{\prime}-\left(\mathrm{CH}_{3}\right)_{2}\right), 1.6 \sim 2.1\left(2 \mathrm{H}, \mathrm{m},-\mathrm{CH}_{2} \mathrm{CH}_{3}\right), 2.9 \sim 3.3(3 \mathrm{H}, \mathrm{m}, 4-\mathrm{H} \times 2,6-\mathrm{H}), 3.53\left(2 \mathrm{H}, \mathrm{s},-\mathrm{SCH} \mathrm{H}_{2} \mathrm{CO}\right), 3.96$ $(1 \mathrm{H}, \mathrm{dt}, J=3$ and $9 \mathrm{~Hz}, 5-\mathrm{H}) .4 .47\left(1 \mathrm{H}, \mathrm{s}, 3^{\prime}-\mathrm{H}\right), 5.21(1 \mathrm{H}, \mathrm{d}, J=14 \mathrm{~Hz},-\mathrm{OC} H \mathrm{H}-\mathrm{Ar}), 5.27(2 \mathrm{H}, \mathrm{s}$, $-\mathrm{OCH}_{2}$-Ar $), 5.50(1 \mathrm{H}, \mathrm{d}, J=14 \mathrm{~Hz},-\mathrm{OCH} H-\mathrm{Ar}), 5.5 \sim 5.7\left(2 \mathrm{H}, \mathrm{m}, 5^{\prime}-\mathrm{H}, 6^{\prime}-\mathrm{H}\right), 7.0 \sim 7.4(1 \mathrm{H}, \mathrm{m}, \mathrm{NH})$, $7.56(2 \mathrm{H}, \mathrm{d}, J=9 \mathrm{~Hz}, \mathrm{Ar}), 7.65(2 \mathrm{H}, \mathrm{d}, J=9 \mathrm{~Hz}, \mathrm{Ar}), 8.21(2 \mathrm{H}, \mathrm{d}, J=9 \mathrm{~Hz}, \mathrm{Ar})$.

Disodium 6-[(5R,6R)-2-Carboxy-6-ethyl-7-oxo-1-azabicyclo[3.2.0]hept-2-ene-3-yl] thioacetylaminopenicillanate (Derivative 25): UV $\lambda_{\max } \mathrm{nm}(8) 299.5(7,400)$ (in $0.1 \mathrm{~m}$ phosphate buffer, $\mathrm{pH} 6.8$ ); ${ }^{1} \mathrm{H}$ NMR ( $\mathrm{D}_{2} \mathrm{O}$, external standard TMS) $\delta 1.41\left(3 \mathrm{H}, \mathrm{t}, J=7.5 \mathrm{~Hz},-\mathrm{CH}_{2} \mathrm{CH}_{3}\right), 1.95,2.0\left(3 \mathrm{H}\right.$, each, s, $\left.2^{\prime}-\left(\mathrm{CH}_{3}\right)_{2}\right)$, $1.9 \sim 2.4\left(2 \mathrm{H}, \mathrm{m},-\mathrm{CH}_{2} \mathrm{CH}_{3}\right), 3.4 \sim 3.9(3 \mathrm{H}, \mathrm{m}, 4-\mathrm{H} \times 2,6-\mathrm{H}), 4.1\left(2 \mathrm{H}, \mathrm{s},-\mathrm{SCH} \mathrm{H}_{2} \mathrm{CO}\right), 4.22(1 \mathrm{H}, \mathrm{dt}, J=3$ and $9 \mathrm{~Hz}, 5-\mathrm{H}), 4.7\left(1 \mathrm{H}, \mathrm{s}, 3^{\prime}-\mathrm{H}\right), 5.9\left(1 \mathrm{H}, \mathrm{d}, J=4 \mathrm{~Hz}, 5^{\prime}-\mathrm{H}\right.$ or $\left.6^{\prime}-\mathrm{H}\right), 6.0\left(1 \mathrm{H}, \mathrm{d}, J=4 \mathrm{~Hz}, 5^{\prime}-\mathrm{H}\right.$ or $\left.6^{\prime}-\mathrm{H}\right)$.

p-Nitrobenzyl 7-[(5R,6R)-6-Ethyl-2-p-nitrobenzyloxycarbonyl-7-oxo-1-azabicyclo[3.2.0]hept-2-ene3-yl] thioacetylaminocephalosporanate-1-oxide (Protected Derivative 26): Rf (silica gel TLC): 0.3 (benzene-acetone, 1:1); UV $\lambda_{\max }^{\mathrm{THF}} \mathrm{nm}(\varepsilon) 268(35,900), 282(26,700), 316(16,800)$; IR $v_{\max }(\mathrm{KBr}) \mathrm{cm}^{-1}$ 1785 ( $\beta$-lactam), 1735, 1720,1690 (ester), 1665 (amide); ${ }^{1} \mathrm{H}$ NMR (DMSO- $d_{6}$ ) $\delta 0.97(3 \mathrm{H}, \mathrm{t}, J=7.5 \mathrm{~Hz}$, $\left.-\mathrm{CH}_{2} \mathrm{CH}_{3}\right), 1.5 \sim 1.9\left(2 \mathrm{H}, \mathrm{m},-\mathrm{CH}_{2} \mathrm{CH}_{3}\right), 2.02\left(3 \mathrm{H}, \mathrm{COCH}_{3}\right), 2.7 \sim 3.5(3 \mathrm{H}, \mathrm{m}, 4-\mathrm{H} \times 2,6-\mathrm{H}), 3.5 \sim 4.2$ $\left(5 \mathrm{H}, \mathrm{m}, 5-\mathrm{H}, \mathrm{SCH}_{2} \mathrm{CO}, 2^{\prime}-\mathrm{H} \times 2\right), 4.65(1 \mathrm{H}, \mathrm{d}, J=13.5 \mathrm{~Hz},-\mathrm{C} H \mathrm{H}-\mathrm{OAc}), 4.97\left(1 \mathrm{H}, \mathrm{d}, J=4 \mathrm{~Hz}, 6^{\prime}-\mathrm{H}\right), 5.26$ $(1 \mathrm{H}, \mathrm{d}, J=13.5 \mathrm{~Hz},-\mathrm{CH} H-\mathrm{OAc}), 5.28(1 \mathrm{H}, \mathrm{d}, J=14 \mathrm{~Hz}, \mathrm{C} H \mathrm{H}-\mathrm{Ar}), 5.47\left(2 \mathrm{H}, \mathrm{s},-\mathrm{OCH} H_{2}-\mathrm{Ar}\right), 5.49(1 \mathrm{H}$, d, $J=14 \mathrm{~Hz},-\mathrm{OCH} H-\mathrm{Ar}), 5.92\left(1 \mathrm{H}, \mathrm{dd}, J=4\right.$ and $\left.9 \mathrm{~Hz}, 7^{\prime}-\mathrm{H}\right), 7.72(4 \mathrm{H}, \mathrm{d}, J=9 \mathrm{~Hz}, \mathrm{Ar}), 8.25(4 \mathrm{H}, \mathrm{d}$, $J=9 \mathrm{~Hz}, \mathrm{Ar}), 8.63(1 \mathrm{H}, \mathrm{d}, J=9 \mathrm{~Hz}, \mathrm{NH})$.

Disodium 7-[(5R,6R)-2-Carboxy-6-ethyl-7-oxo-1-azabicyclo[3.2.0]hept-2-ene-3-yl]thioacetylaminocephalosporanate-1-oxide (Derivative 26): UV $\lambda_{\max } \mathrm{nm}(\varepsilon) 260(11,900), 299(7,700)$ (in $0.01 \mathrm{M}$ phosphate buffer, pH 7.5); ${ }^{1} \mathrm{H}$ NMR (D $2 \mathrm{O}$, external standard TMS) $\delta 1.45\left(3 \mathrm{H}, \mathrm{t}, J=7.5,-\mathrm{CH}_{2} \mathrm{CH}_{3}\right), 2.0 \sim 2.5(2 \mathrm{H}$, $\left.\mathrm{m}, \mathrm{CH}_{2} \mathrm{CH}_{3}\right), 2.56\left(3 \mathrm{H}, \mathrm{s}, \mathrm{COCH}_{3}\right), 3.3 \sim 3.85(3 \mathrm{H}, \mathrm{m}, 4-\mathrm{H} \times 2,6-\mathrm{H}), 4.16\left(2 \mathrm{H}, \mathrm{s}, \mathrm{SCH} \mathrm{H}_{2} \mathrm{CO}\right), 3.85 \sim 4.6$ $\left(2 \mathrm{H}, \mathrm{m}, 2^{\prime}-\mathrm{H} \times 2\right), 4.48(1 \mathrm{H}, \mathrm{dt}, J=3$ and $9 \mathrm{~Hz}, 5-\mathrm{H}), 5.14(1 \mathrm{H}, \mathrm{d}, J=13 \mathrm{~Hz}, \mathrm{CH}-\mathrm{HAc}), 5.39(1 \mathrm{H}, \mathrm{d}$, $\left.J=4.5 \mathrm{~Hz}, 6^{\prime}-\mathrm{H}\right), 5.52(1 \mathrm{H}, \mathrm{d}, J=13 \mathrm{~Hz}, \mathrm{CH} H-\mathrm{OAc}), 6.36\left(1 \mathrm{H}, \mathrm{d}, J=4.5 \mathrm{~Hz}, 7^{\prime}-\mathrm{H}\right)$.

p-Nitrobenzyl 6-Ethyl-3-(5-nitropyridin-2-yl)thio-7-oxo-1-azabicyclo[3.2.0]hept-2-ene-2-carboxylate (Protected Derivative 31): Rf (silica gel TLC): 0.39 (benzene-acetone, 10:1); $[\alpha]_{\mathrm{D}}^{23} 33.0^{\circ}(c 0.5$, THF), UV $\lambda_{\max }^{\mathrm{THF}} \mathrm{nm}(\varepsilon) 269(16,300), 356(15,200) ; \mathrm{IR} v_{\max }\left(\mathrm{CHCl}_{3}\right) \mathrm{cm}^{-1} 1780$ ( $\beta$-lactam), 1720 (ester); ${ }^{1} \mathrm{H} \mathrm{NMR}\left(\mathrm{CDCl}_{3}\right) \delta 1.06\left(3 \mathrm{H}, \mathrm{t}, J=7.5 \mathrm{~Hz}, \mathrm{CH}_{2} \mathrm{CH}_{3}\right), 1.66 \sim 2.07\left(2 \mathrm{H}, \mathrm{m},-\mathrm{CH}_{2} \mathrm{CH}_{3}\right), 3.03(1 \mathrm{H}$, dd, $J=9$ and $18 \mathrm{~Hz}, 4-\mathrm{Ha}), 3.00 \sim 3.33(1 \mathrm{H}, \mathrm{m}, 6-\mathrm{H}), 3.58(1 \mathrm{H}, \mathrm{dd}, J=9$ and $18 \mathrm{~Hz}, 4-\mathrm{Hb}), 4.03(1 \mathrm{H}, \mathrm{dt}, J=3$ and $9 \mathrm{~Hz}, 5-\mathrm{H}), 5.22(1 \mathrm{H}, \mathrm{d}, J=14 \mathrm{~Hz}, \mathrm{C} H \mathrm{H}-\mathrm{Ar}), 5.49(1 \mathrm{H}, \mathrm{d}, J=14 \mathrm{~Hz}, \mathrm{CH} H-\mathrm{Ar}), 7.45\left(1 \mathrm{H}, \mathrm{d}, J=9 \mathrm{~Hz}, 3^{\prime} \mathrm{H}\right)$, $8.30\left(1 \mathrm{H}, \mathrm{dd}, J=3\right.$ and $\left.9 \mathrm{~Hz}, 4^{\prime}-\mathrm{H}\right), 9.24\left(1 \mathrm{H}, \mathrm{d}, J=3 \mathrm{~Hz}, 6^{\prime}-\mathrm{H}\right), \mathrm{MS}(m / z) 470\left(\mathrm{M}^{+}\right)$.

3-(5-Aminopyridin-2-yl)thio-6-ethyl-7-oxo-1-azabicyclo[3.2.0]hept-2-ene-2-carboxylic Acid (Derivative 31): UV $\lambda_{\max } \mathrm{nm}(\varepsilon) 261.5(10,900), 304.5(12,500)$ (in $0.1 \mathrm{~m}$ phosphate buffer, $\mathrm{pH} 7.2$ ); ${ }^{1} \mathrm{H}$ NMR $\left(\mathrm{D}_{2} \mathrm{O}\right.$, external standard TMS) $\delta 1.36\left(3 \mathrm{H}, \mathrm{t}, J=7.5 \mathrm{~Hz}, \mathrm{CH}_{2} \mathrm{CH}_{3}\right), 1.90 \sim 2.32\left(2 \mathrm{H}, \mathrm{m}, \mathrm{CH}_{2} \mathrm{CH}_{3}\right), 2.80 \sim 3.80$ $(3 \mathrm{H}, \mathrm{m}, 4-\mathrm{H} \times 2,6-\mathrm{H}), 4.00 \sim 4.40(1 \mathrm{H}, \mathrm{m}, 5-\mathrm{H}), 7.63\left(1 \mathrm{H}, \mathrm{dd}, J=3\right.$ and $\left.8 \mathrm{~Hz}, 4^{\prime}-\mathrm{H}\right), 7.92(1 \mathrm{H}, \mathrm{d}, J=8 \mathrm{~Hz}$, $\left.3^{\prime}-\mathrm{H}\right), 8.50\left(1 \mathrm{H}, \mathrm{d}, J=3 \mathrm{~Hz}, 6^{\prime}-\mathrm{H}\right)$.

$p$-Nitrobenzyl 6-Ethyl-3-[5-(4-pyridyl)-1 $H$-1,2,4-triazol-3-yl]thio-7-oxo-1-azabicyclo[3.2.0]hept-2-ene2-carboxylate (Protected Derivative 35): Rf (silica gel TLC): 0.4 (benzene-acetone, $1: 1$ ); UV $\lambda_{\max }^{\mathrm{CHCl}_{3}}$ $\mathrm{nm}(\varepsilon) 262(18,400), 310(13.900)$; IR $v_{\max }\left(\mathrm{CHCl}_{3}\right) \mathrm{cm}^{-1} 1775$ ( $\beta$-lactam), 1705 (ester); ${ }^{1} \mathrm{H}$ NMR $\left(\mathrm{CDCl}_{3}\right)$ $\delta 0.98\left(3 \mathrm{H}, \mathrm{t}, J=7 \mathrm{~Hz},-\mathrm{CH}_{2} \mathrm{CH}_{3}\right), 1.77\left(2 \mathrm{H}, \mathrm{m},-\mathrm{CH}_{2} \mathrm{CH}_{3}\right), 2.9 \sim 3.2(3 \mathrm{H}, \mathrm{m}, 4-\mathrm{H} \times 2,6-\mathrm{H}), 3.90(1 \mathrm{H}$, $\mathrm{dt}, J=3$ and $9 \mathrm{~Hz}, 5-\mathrm{H}), 5.25(1 \mathrm{H}, \mathrm{d}, J=14 \mathrm{~Hz}, \mathrm{CHH}-\mathrm{Ar}), 5.26(1 \mathrm{H}, \mathrm{br}, \mathrm{NH}), 5.48(1 \mathrm{H}, \mathrm{d}, J=14 \mathrm{~Hz}$, $\mathrm{CH} H-\mathrm{Ar}), 7.57(2 \mathrm{H}, \mathrm{d}, J=9 \mathrm{~Hz}, \mathrm{Ar}), 7.92\left(2 \mathrm{H}, \mathrm{d}, J=6 \mathrm{~Hz}, 3^{\prime}-\mathrm{H}, 5^{\prime}-\mathrm{H}\right), 8.12(2 \mathrm{H}, \mathrm{d}, J=9 \mathrm{~Hz}, \mathrm{Ar}), 8.68$ $\left(2 \mathrm{H}, \mathrm{d}, J=6 \mathrm{~Hz}, 2^{\prime}-\mathrm{H}, 6^{\prime}-\mathrm{H}\right)$.

6-Ethyl-3-[5-(4-pyridyl)-1 H-1,2,4-triazol-3-yl] thio-7-oxo-1-azabicyclo[3.2.0] hept-2-ene-2-carboxylic Acid (Derivative 35): As the amount of derivative 35 was not enough for measuring the physico-chemical properties, only its biological properties were evaluated. 


\section{Acknowledgment}

The authors wish to thank Prof. Y Yamada, Tokyo College of Pharmacy, for his helpful advice in this work.

\section{References}

1) Sakamoto, M.; T. Ishikura \& Y. Fukagawa: Synergism of PS-5 with penicilins and cephalosporins in antimicrobial activity against $\beta$-lactamase-resistant Gram-negative microorganisms. J. Antibiotics 37: 1414 1422, 1984

2) Sakamoto, M.; H. Iguchi, K. Okamura, S. Hori, Y. Fukagawa, T. Ishikura \& J. Lein: PS-5, a new $\beta$-lactam antibiotic. II. Antimicrobial activity. J. Antibiotics 32: $272 \sim 279,1979$

3) Sakamoto, M.; N. Shibamoto, H. Iguchi, K. Okamura, S. Hori, Y. Fukagawa, T. Ishikura \& J. Lein: PS-6 and PS-7, new $\beta$-lactam antibiotics. In vitro and in vivo evaluation. J. Antibiotics 33: 1138 1145, 1980

4) Shibamoto, N.; M. Nishino, K. Okamura, Y. Fukagawa \& T. Ishikura: PS-8, a minor carbapenem antibiotic. J. Antibiotics 35: 763 765, 1982

5) Shibamoto, N.; M. Sakamoto, H. Iguchi, H. Tone, Y. Fukagawa \& T. Ishikura: Pharmacological studies on carbapenem antibiotics. I. Metabolism of PS-5 in animal tissues. J. Antibiotics 35: 721 728, 1982

6) Shibamoto, N.; M. Sakamoto, Y. Fukagawa \& T. Ishikura: Pharmacological studies on carbapenem antibiotics. II. Isolation of a PS-5-inactivating factor from the rat kidney. J. Antibiotics 35: 729 735, 1982

7) Yamamoto, K.; T. Yoshioka, Y. Kato, K. Isshiki, M. Nishino, F. Nakamura, Y. Shimauchi \& T. Ishikura: Versatile chemical modification of the C-2 side chain of carbapenem antibiotics. Tetrahedron Lett. 23: 897 900, 1982

8) Yamamoto, K.; T. Yoshioka, Y. Kato, K. Isshiki, M. Nishino, F. Nakamura, Y. Shimauchi \& T. Ishikura: Chemical modification of carbapenem antibiotics. Versatile methods for displacement of the C-3 sulfur side chain of carbapenems with other thiol groups. J. Antibiotics 36: $407 \sim 415,1983$

9) Basker, M. J.; R. J. Boon \& P. A. Hunter: Comparative antibacterial properties in vitro of seven olivanic acid derivatives: MM 4550, MM 13902, MM 17880, MM 22380, MM 22381, MM 22382 and MM 22383. J. Antibiotics 33: $878 \sim 884,1980$.

10) Sakamoto, M.; Yamamoto, H. Iguchi, H. Tone, T. Ishikura, T. Yoshioka \& Y. Fukagawa: Comparative in vitro and in vivo dehydropeptidase-I stabilities of PS-5 derivatives modified at the C-3 side chain. Chem. Pharm. Bull., to submitted

11) Shibamoto, N.; T. Yoshioka, M. Sakamoto, Y. Fukagawa \& T. Ishikura: Pharmacological studies on carbapenem antibiotics. III. Chemical structure of PS-5D III, the primary renal metabolite of PS-5. J. Antibiotics 35: $736 \sim 741,1982$

12) Davis, R. B. \& E. P. ABraHAM: Metal cofactor requirements of $\beta$-lactamase. II. Biochem. J. 143: 129 135, 1974

13) Saino, Y.; F. Kobayashi, M. Inoue \& S. Mitsuhashi: Purification and properties of inducible penicillin $\beta$-lactamase isolated from Pseudomonas maltophilia. Antimicrob. Agents Chemother. 22: $564 \sim 570,1982$

14) Sawai, T.; K. Matsuba, A. Tamura \& S. Yamagishi: The bacterial outer-membrane permeability of $\beta$-lactam antibiotics. J. Antibiotics 32: 59 65, 1979

15) OKamura, K.; M. Sakamoto, Y. Fukagawa, T. Ishikura \& J. Lein: PS-5, a new $\beta$-lactam antibiotic. III. Synergistic effects and inhibitory activity against a $\beta$-lactamase. J. Antibiotics 32: $280 \sim 286,1979$

16) FuKagawa, Y.; T. TAKeI \& T. Ishikura: Inhibition of $\beta$-lactamase of Bacillus licheniformis $749 / \mathrm{C}$ by compound PS-5, a new $\beta$-lactam antibiotic. Biochem. J. 185: $177 \sim 188,1980$

17) Hunter, P. A.; K. Coleman, J. Fisher \& D. TAylor: In vitro synergistic properties of clavulanic acid, with ampicillin, amoxycillin and ticarcillin. J. Antimicrob. Chemother. 6:455 470, 1980

18) Okamura, K.; A. Koki, M. Sakamoto, K. Kubo, Y. Mutoh, Y. Fukagawa, K. Kouno, Y. Shimauchi, T. IsHIKURA \& J. LEIN: Microorganisms producing a new $\beta$-lactam antibiotic. J. Ferment. Technol. 57: 265 272, 1979

19) Fukagawa, Y.; K. Kubo, T. Ishikura \& K. Kouno: Deacetylation of PS-5, a new $\beta$-lactam compound. I. Microbial deacetylation of PS-5. J. Antibiotics 33: 543 549, 1980

20) Kahan, J. S.; F. M. Kahan, R. Goegelman, S. A. Currie, M. Jackson, E. O. Stapley, T. W. Miller, A. K. Miller, D. Hendlin, S. Mochales, S. Hernandez, H. B. Woodruff \& J. Birnbaum: Thienamycin, a new $\beta$-lactam antibiotic. I. Discovery, taxonomy, isolation and physical properties. J. Antibiotics 32: $1 \sim 12,1979$

21) Leanza, W. J.; K. J. Windonger, T. W. Miller \& B. G. Christensen: N-Acetimidoyl- and $N$-formimidoylthienamycin derivatives: Antipseudomonal $\beta$-lactam antibiotics. J. Medicinal Chem. 22: 1435 1436, 1979

22) MAK, C. P. \& H. FLIRI (Sandoz): Fluoralkylated carbapenem derivatives. U.S. 4720490, Jan. 19, 1988

23) Japan Society of Chemotherapy: The revised method of determination of MIC values. Chemotherapy 29: 76 79, 1981 